\title{
1. What does the history of the Common Agricultural Policy tell us? David Harvey
}

\section{INTRODUCTION}

Why do we need an agricultural policy? Food and, therefore, farming are obviously fundamental to civilization, and food security is a primary goal for any government. Yet history, economic theory and empirical analysis strongly suggest that governments cannot, directly and reliably, command and control farming and food production. ${ }^{1}$ Private ownership and operation of land by farmers, and secure rights to specialize and trade - in other words, free and secure markets - have proved historically a more reliable means for securing food supplies than direct governmental control. On the other hand, almost without fail, national governments find it necessary to build and then defend agricultural policies. Furthermore, there is a clear pattern to government intervention in agriculture.

In the early stages of economic development, food security is of paramount importance, while the major economic sector is agriculture and most of the population live and work in rural areas. In these circumstances, farming tends to be taxed (as the largest and most productive sector of the economy) and food consumption tends to be subsidized. ${ }^{2}$ However, economic development involves a major socio-economic transition from a predominantly agrarian and rural society to an urban, commercial and industrial economy. This transition is typically accompanied by a fall in the relative earnings in agriculture compared with those elsewhere. Indeed, this change in relative incomes is seen as a major driver of economic development and structural change, as well as being a consequence.

Rising real incomes mean that the price of food declines in political importance, while depressed incomes in agriculture become more pressing. ${ }^{3}$ The typical policy stance shifts from taxing agriculture to subsidizing and supporting farming. Swinnen reviews the main explanations which have been offered for this general tendency: ${ }^{4}$

As average incomes increase in an economy, changes in the structure of the economy affect the distribution and the size of political costs and benefits of agricultural protection and thus the governments' political incentives in decision making. For example, the share of food in consumer

1 See, e.g., K. Anderson (ed.), Distortions to Agricultural Incentives: A Global Perspective, 1955-2007 (The World Bank and Palgrave Macmillan, 2009).

2 Ibid. See also P. Lindert, 'Historical Patterns of Agricultural Policy', in C. Timmer (ed.), Agriculture and the State (Cornell University Press, 1991) 29.

3 See, e.g., Organisation for Economic Co-operation and Development (OECD), 'Executive Summary', in Global Food Security: Challenges for the Food and Agricultural System (OECD, 2013) (available at http://dx.doi.org/10.1787/9789264195363-3-en).

4 J. Swinnen, The Political Economy of Agricultural Policies: The Literature to Date (World Bank, 2009) 4. 


\section{Research handbook on EU agriculture law}

expenditures falls as a share of total expenditure, reducing the opposition to agricultural protection of not only consumers but also capital owners in other sectors who oppose the (wage) inflation pressures that come from increased food costs with agricultural protection.

Another factor that coincides with economic growth is a declining share of agriculture in employment. With a declining number of farmers (in relative terms), the per head costs of increasing farm incomes through protection decrease for the rest of society.

Further, typically incomes in the rest of the economy grow faster than in agriculture in the course of a country's economic development. This creates political incentives (both on the demand side (farmers) and on the supply side (politicians)) to exchange government transfer in exchange for political support. When incomes from farming decline relative to opportunities in other sectors, farmers look for non-market sources of income such as government support, either because returns to investment in lobbying activities are larger than in market activities, or because willingness to vote for/support politicians is strong. For similar reasons governments are more likely to support sectors with a comparative disadvantage than sectors with a comparative advantage. These explanations are consistent with observations of agricultural protection being countercyclical to market conditions.

Political economy theories predict that exports will be subsidized less (or taxed more) than imports because of differences in demand and supply elasticities. The distortions (deadweight costs) and transfer costs of policy intervention typically increase with the commodity's trade balance, i.e., when net exports increase. Another factor is the differential effect on government border tax revenues. Therefore protection of the sector in many countries is found to increase with decreases in their agricultural trade surplus.

As Swinnen also notes, a refinement of this general explanation is that agricultural protection and support is part of a 'social contract' to invest strongly in innovation and research and development (R\&D) throughout the economy, stimulating productivity growth and restructuring. It is clear that economic development cannot happen without both $\mathrm{R} \& \mathrm{D}$ and restructuring, perhaps the more so in agriculture (at least in the early stages of development). In simple terms, more people have to be fed (as populations grow) by fewer people engaged in agriculture (for economic development to occur), which requires a substantial growth in agricultural productivity. However, as incomes grow and the demand for food becomes more price inelastic, so expansion in food supplies, fuelled by $R \& D$, results in a falling real price of food to the benefit of consumers at the expense of farmers (at least to the extent that farmers cannot exit the industry for better incomes elsewhere in the economy). Agricultural protection can be used to cushion the blow for the least mobile, as suggested by Rausser and also by de Gorter, Nielson and Rausser, ${ }^{5}$ and for which there is empirical evidence. ${ }^{6}$

Swinnen further reviews more recent political economy contributions for their relevance to the explanation of the extent of agricultural protection. ${ }^{7}$ Of most importance for the explanation of the development of the Common Agricultural Policy (CAP) appear

5 See G. Rausser, 'Political economic markets: PERTs and PESTs in food and agriculture', (1982) 64 American Journal of Agricultural Economics 821; and H. de Gorter, D. Nielson and G. Rausser, 'Productive and predatory public policies: research expenditures and producer subsidies in agriculture', (1992) 74 American Journal of Agricultural Economics 27.

6 See, e.g., J. Swinnen, A. Banerjee and H. de Gorter, 'Economic development, institutional change, and the political economy of agricultural protection: an econometric study of Belgium since the 19th century', (2001) 26 Agricultural Economics 25.

7 Above $\mathrm{n} 4$. 
to be the ruling preferences (or preferences of the rulers) and the constraints (or drivers) of voting rules, which constrain (or translate constituency) preferences. ${ }^{8}$

Pokrivcak, Crombez and Swinnen (2006) show how agricultural policy reforms [in the EU] are determined by a complex interaction of majority voting rules, changes in the external environment, and the preferences of the European Commission (the agenda setting bureaucracy in Brussels). The authors show that reforms are not possible unless external changes are sufficiently large and the influence of the bureaucracy depends on voting rules.

Here, the two most prominent changes in the external environment affecting the European Union (EU) and its agriculture over the life of the CAP have been: (i) the collapse of the Berlin Wall in 1989 leading to the unification of Germany and the enlargement of the EU to include the Central and Eastern European countries (CEE) formally under Soviet rule; and (ii) the regulatory capture of agriculture within the legislative framework of the World Trade Organization (WTO), following the conclusion in 1994 of the Uruguay Round Agreement on Agriculture (AoA). The major internal changes have been the successive enlargements of the EU and the reforms to the voting procedures. And, most recently, the Lisbon Treaty, which came into force in 2009, extended the role of the European Parliament under the ordinary legislative procedure when regulating the CAP.

However, as economies develop further and the agrarian population continues to decline, so the expense and distortions of intervention in agriculture become more problematic. The focus of agricultural policy tends to shift from 'simply' supporting farmers to paying farmers for the delivery of environmental and other non-market goods and services, and towards more general rural development. The evolution of the EU's agricultural policy over the last 50 years has clearly shown these trends, notwithstanding the major expansion of the EU over this period, especially during this century.

\section{A HISTORY OF THE CAP}

\subsection{The Origins}

The history of the CAP clearly illustrates this conceptual framework of agricultural protection. The CAP did not appear from nowhere - it evolved from the Member States' previous agricultural policies. Tracy provides the definitive account of these histories and of the development of the CAP up to $1988 .{ }^{9}$ The story begins with the major challenge faced by European countries during the industrial revolution and the opening up of the New World during the nineteenth century. The dramatic decline in the cost of transport, both by land and sea, coupled with the development of, in particular, grain production in North America meant a seismic shift in Europe's comparative advantage away from

8 Ibid, 9-10 (citing J. Pokrivcak, C. Crombez and J. Swinnen, 'The status quo bias and reform of the Common Agricultural Policy: impact of voting rules, the European Commission, and external changes', (2006) 33 European Review of Agricultural Economics 562).

9 M. Tracy, Government and Agriculture in Western Europe, 1880-1988 (3rd Ed., Harvester Wheatsheaf, 1989). 
land-intensive products, like grain, into labour-intensive activities, such as intensive livestock and manufacturing.

The Netherlands and Denmark made the most of the opportunities for intensive livestock production, fed by cheap feed grains. Their increasing exports put further pressure on other European farm markets, notably in the United Kingdom (UK) and Germany. Germany reacted by raising tariffs on imported grains to protect their own markets. The UK, however, did nothing to ease the resulting agricultural depression at the end of the nineteenth century, partly because the option of taxing imports from its Commonwealth and colonial partners was not politically realistic, and partly reflecting the decline in the political power of the farm sector. The 'rationalization' of British agriculture into fewer and larger farms, already substantial compared with its European neighbours, gained further momentum as a result, both assisted by and encouraging further adoption of substantial mechanization. In contrast, farm structures in France and Germany hardly changed, and the eventually inevitable reduction in the farm labour force was postponed.

The second major challenge was the Great Depression of the 1930s, which persuaded all countries to increase protection and support of their agricultural sectors, through increased tariffs on the continent and the beginnings of subsidies and marketing support in the UK. Of course, when all countries raise tariffs and restrict trade, the result is that economic depression is prolonged rather than relieved. In the historical event, the advent and subsequent catastrophe of World War II effectively ended the depression, though the cure was hardly better than the disease.

Figure 1.1 illustrates the relative importance of farming in Western Europe during the 1950s. As can be seen, agriculture was still a major employment sector in most countries, with the share of total employment as high as 40 per cent, yet already below 5 per cent in the UK. Farm employment was declining in importance in all countries during that decade, although less so in those countries (Belgium, Netherlands and the UK) where farm employment had already adjusted sufficiently to make the share of gross domestic product (GDP) in agriculture (also tending to decline) almost equivalent to the share of employment. But over most of Europe, the share of GDP generated in farming was substantially below the share of employment, indicating a substantial income gap between incomes in farming and other sectors of the economy.

Farm policies could have been expected to reflect these different economic structural realities in different ways in each of the European states. But, in addition, the international post-war determination resulted in the establishment of the International Monetary Fund, the World Bank and the General Agreement on Tariffs and Trade (GATT), following the Bretton Woods international conference in 1944, with the aims of rebuilding shattered economies and promoting international cooperation. In Europe, the political process of reconstruction and conciliation began with the formation of the European Coal and Steel Community in 1952, forged between Germany, France, Italy, the Netherlands, Belgium and Luxembourg, marking a first step towards a supranational Europe. The second and major step was the formation by the same countries of the European Economic Community (EEC) in 1957, under the Treaty of Rome. 


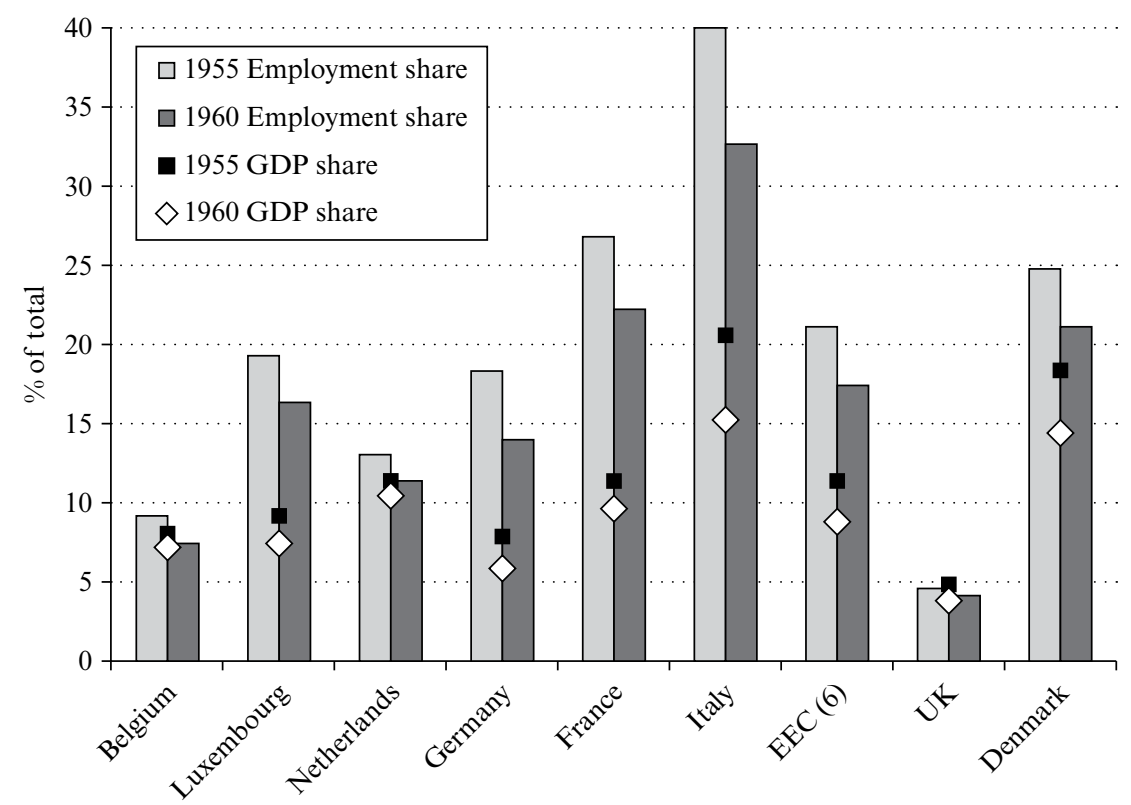

Source: OECD, Agricultural Statistics 1955-1968 (OECD, 1969).

Figure 1.1 Agriculture in Europe, 1955-60

\subsection{The Birth of the CAP}

Following World War II, the agricultural policy emphasis in Europe was clearly towards commodity price support, either through tariff protection (especially in Germany), or through subsidies (as in the UK). The aims were to raise agricultural output to secure food supplies following the experiences of the war, and also to secure farm incomes and employment following demobilization. Although self-sufficiency ratios had improved, farm incomes remained depressed. With specific reference to France, Germany and Italy, farms remained too small or fragmented to be viable. Inclusion of agriculture within the Treaty of Rome was essential both economically and politically (see Figure 1.1). Economically, the formation of a common market and customs union required the inclusion of agriculture and food, simply because of the importance of food in both production and consumption patterns of the time. Politically, the essential compromise between German and French national interests required that France, as the predominant agricultural producer within the EEC, gain remunerative Community agricultural markets to offset the competitiveness of German industry in a common market.

In addition to common trade and transport policies, the EEC Treaty established the CAP (Articles 38 to 47), with the objectives set out in Article 39(1):

(a) to increase agricultural productivity by promoting technical progress and by ensuring the rational development of agricultural production and the optimum utilisation of the factors of production, in particular labour; 


\section{Research handbook on EU agriculture law}

(b) thus to ensure a fair standard of living for the agricultural community, in particular by increasing the individual earnings of persons engaged in agriculture;

(c) to stabilise markets;

(d) to assure the availability of supplies; and,

(e) to ensure that supplies reach consumers at reasonable prices.

The Stresa Conference was then convened in 1958 by Sicco Mansholt (the Dutch vicepresident of the Commission responsible for agriculture) to establish how these objectives could be met. Despite Mansholt's misgivings that centrally fixed prices would disconnect both producers and consumers from market forces, the conference agreed that agriculture should be supported through guaranteed prices rather than direct aids to farmers. ${ }^{10}$ By 1960, the common principles for the policy were established as: Market Unity (free internal market for agricultural and food products at common prices); Community Preference; and Common Financial Responsibility. The implementation of these principles was through the common market organizations, which were finally ratified by the Council of Ministers in 1962 (at least for cereals, pig meat, eggs, poultry meat, fruit and vegetables, and wine, with other products added later following interim measures to assist market unity). The European Agricultural Guidance and Guarantee Fund (EAGGF) was established to finance the operations of the CAP (a Guarantee Section for prices and a Guidance Section for structural measures).

The fundamental questions of what methods to use to achieve the price guarantee and of the level at which to set the guarantee price had to be determined first for cereals. Grains are both a major agricultural product and a major cost for livestock farmers, especially for intensive pig and poultry farmers. Without determining the mechanisms and levels of support for cereals, it is neither possible nor sensible to define them for other commodities. Although the option was suggested of providing support through variable subsidies based on market prices (the UK deficiency payment scheme), this had no chance of acceptance because of the budgetary cost for the major commodities, although it was adopted for oilseeds and durum wheat, which were more localized and minor commodities at the time. ${ }^{11}$

The obvious mechanism was the import tariff, not least since this mechanism was already in place in many of the EEC countries. It provided not only protection from (low) world prices, but also insulation from their manifest variability, which was achieved by implementation as a variable levy, adjusting to accommodate world prices as they rose and fell. In addition, it had the advantage of raising revenue (so long as the EEC remained a net importer) rather than exposing the infant EEC budget to substantial expenditure on subsidies. To support prices in exporting countries (France), a complementary system of intervention purchases and export refunds was also needed. A basic framework was

10 A. Teasdale and T. Bainbridge, The Penguin Companion to European Union (4th Ed., Penguin, 2012), Stresa Conference (available at http://penguincompaniontoeu.com/additional entries/stresa-conference). See also A. Fearne, 'The History and Development of the CAP 1945-1990', in C. Ritson and D. Harvey (eds.), The Common Agricultural Policy (2nd Ed., CAB International, 1997) 16; R. Fennell, The Common Agricultural Policy of the European Community (BSP Professional Books, 1987) 1-15; and F. Synder, Law of the Common Agricultural Policy (Sweet and Maxwell, 1985).

11 Tracy, (above n 9) 270. 
thus established consisting of threshold prices (for imports to the EEC from elsewhere) and intervention prices (at which the EEC would purchase surplus production for storage and later sale, often through subsidized export to third countries). Both these prices were derived from the target price, which was fixed annually by the Council for individual agricultural products.

Although, perhaps with the benefit of hindsight, the choice of the appropriate instruments of support was straightforward, the actual determination of both the instruments and the level of support were protracted, with the Netherlands championing resistance to the insulation and protection of EEC cereals markets against world prices because of the importance of its livestock sector which was so heavily dependent on imported feedstuffs. ${ }^{12}$ The eventual level of the target price for each product (from which were derived both the intervention and threshold prices) was also, in hindsight, effectively pre-determined. It was inconceivable that German interests would allow these prices to be set very much below the ruling German level of protection, and so it proved. The French, in particular, could not be expected to resist high support prices very strongly. As Tracy says: ${ }^{13}$

Bearing in mind the diversity of national systems of agricultural support and protection, and the extent of the adjustments required to create a single price level, the introduction of common market regimes in the Community of Six was a remarkable achievement, possible only in the context of a strong political commitment.

\subsection{The Early Days}

By 1967-68 the EEC prices had become common within the original six Member States and the common border variable levy was in place. As a result, EEC prices were typically some 150-200 per cent above the 'world' price (third country offer price), and as much as 400 per cent above in the case of butter. Until 1968, the EEC budget had been funded through interim financial contributions from each Member State, to be progressively replaced with the Community's 'own resources' - a combination of receipts from the common customs duties including, importantly, those from the variable levies, and also (from 1978) a transfer from each Member State based on value added tax (VAT). Initially, the VAT resource was set at a maximum of 1 per cent of the share of the economy to which VAT applies, assessed on a common basis across all Member States. As this system of own resources came into effect, the European Parliament was given more budgetary power. From 1975, it had the final word on non-compulsory expenditure (in other words, excluding compulsory expenditure resulting directly from the Treaty of Rome, which covered most agricultural expenditure) and could reject the annual budget. Once directly elected (as from 1979) the European Parliament's position and legitimacy as the final budget authority was strengthened. In consequence, the annual budgetary process between it and the Council became increasingly difficult.

As can be seen from Figure 1.2, the early days of the EU were completely funded through the common customs duties, with agricultural levies being the major contributor.

12 Ibid, 252-69.

13 Ibid, 269. 

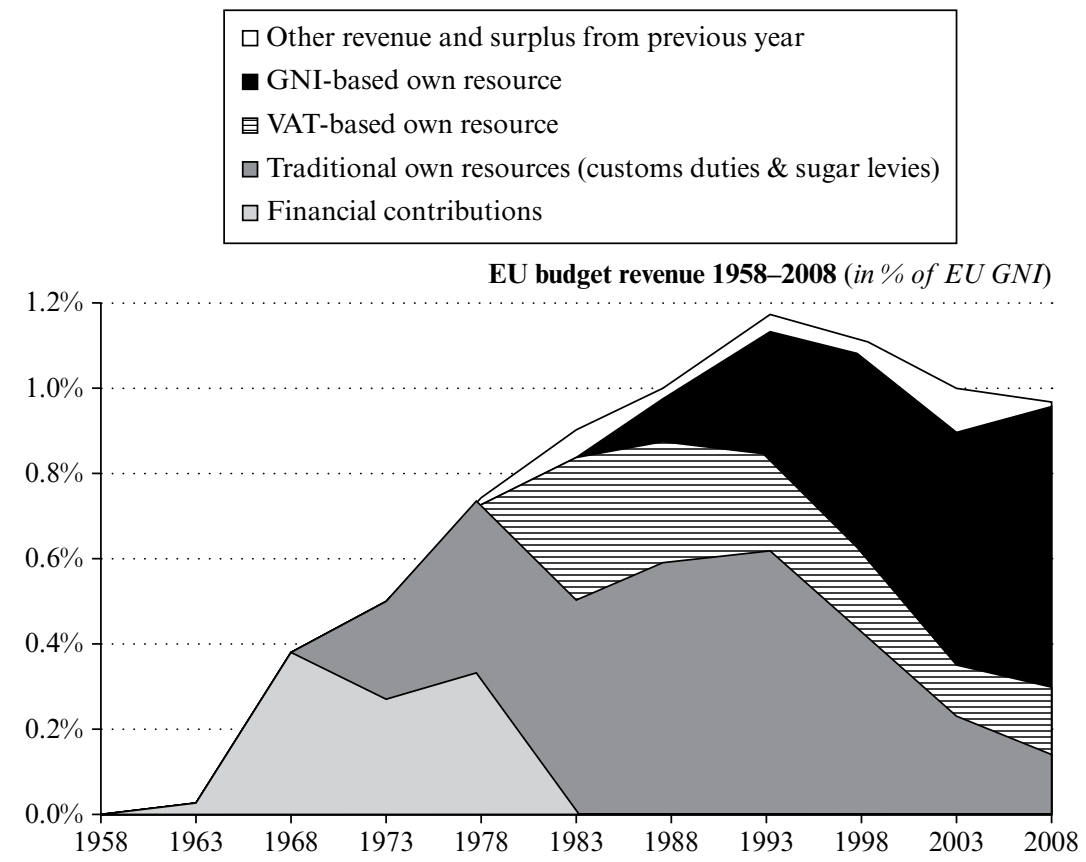

Note: GNI - Gross National Income.

Source: European Commission, Reforming the Budget, Changing Europe (available at http://ec.europa.eu/ budget/reform2008/history/history1957_en.htm).

Figure 1.2 EU budget revenue, 1958-2008

Figure 1.3 shows that EU spending during these early stages was also predominantly on agriculture. Mansholt's misgivings about setting internal support prices too high were manifestly realized as the original six producers responded to the incentives to overproduce for the internal market. Mountains of butter and grain and lakes of wine began to build up in intervention stores, with no hope of being resold other than with expensive export refunds. At the end of 1968, Mansholt, as the Commissioner responsible for agriculture, sent a memorandum to the Council outlining a major reform of the CAP ${ }^{14} \mathrm{He}$ observed that, despite the evident success of the policy in increasing production, farm incomes had not improved, and that the only way of helping farm incomes was for farms to become larger, and therefore fewer. His plan involved limiting price support, especially for surplus commodities, encouraging small farmers to leave through retirement grants and retraining, and 5 million hectares ( 7 per cent of utilized agricultural area) being taken out of production during the next decade.

14 European Commission, COM (68) 1000, Memorandum sur la Réforme de l'Agriculture dans la Communauté Économique Européenne (better known as the Mansholt Plan). See also discussion of the plan in the works noted, above $\mathrm{n} 11$. 


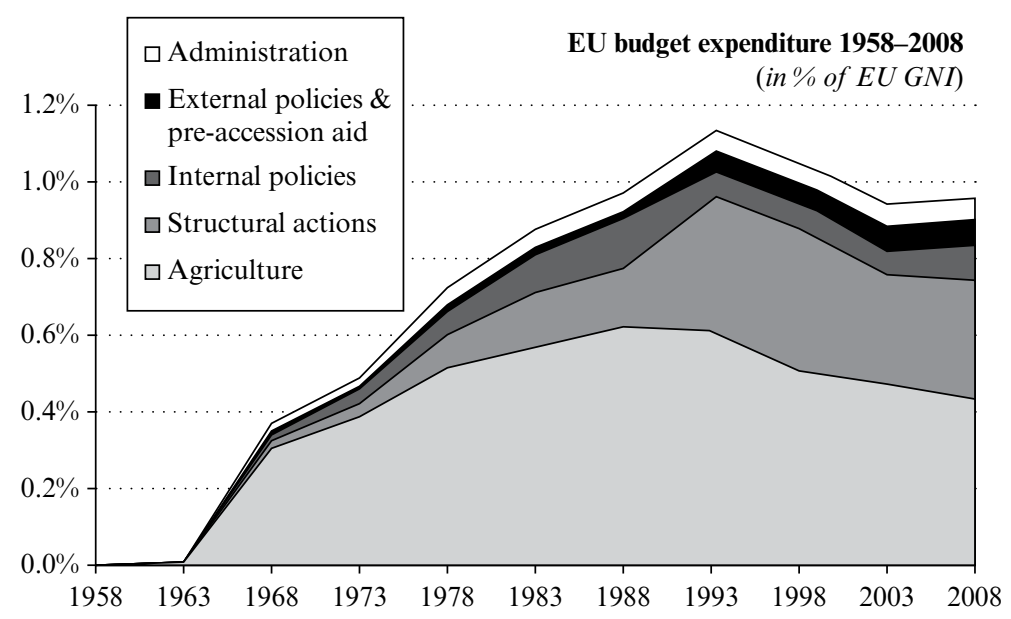

Note: GNI - Gross National Income.

Source: European Commission, Reforming the Budget, Changing Europe (available at http://ec.europa.eu/ budget/reform2008/history/history1957_en.htm).

Figure 1.3 EU budget spending, 1958-2008

However, the plan was far too ambitious for the EU's farm sector and their ministers, and was largely rejected, with only three directives being approved in 1972 (modernization of agricultural holdings, cessation of farming and training of farmers).${ }^{15}$ Nevertheless, farm numbers in fact continued to decline at the rate envisaged by Mansholt. Between 1958 and 1979 more than 10 million people left EU agriculture. ${ }^{16}$

\subsection{The First Enlargement}

The immediate crisis of overproduction, ever-expanding intervention stores and escalating export refund spending was averted somewhat in 1973 with the first enlargement to include the UK, Ireland and Denmark. The UK, as a major net food importer, proved a welcome market for Europe's growing surpluses, despite the fact that the accession agreement included both a seven year transition period and also significant continued access arrangements between the UK and its Commonwealth partners (especially Australia, Canada and New Zealand).

However, the accessions in 1973 coincided with the major world commodity price spike

15 Council Directive 72/159/EEC of 17 April 1972 on the modernization of farms, [1972] OJ L96/1; Council Directive 72/160/EEC of 17 April 1972 concerning measures to encourage the cessation of farming and the reallocation of utilized agricultural areas for the purposes of structural improvement, [1972] OJ L96/9; and Council Directive 72/161/EEC of 17 April 1972 concerning the provision of socio-economic guidance for and the acquisition of occupational skills by persons engaged in agriculture, [1972] OJ L96/15.

16 European Commission, Reflections on the Common Agricultural Policy, EC Bulletin, Supplement 6/80 (European Commission, 1981) 7. 


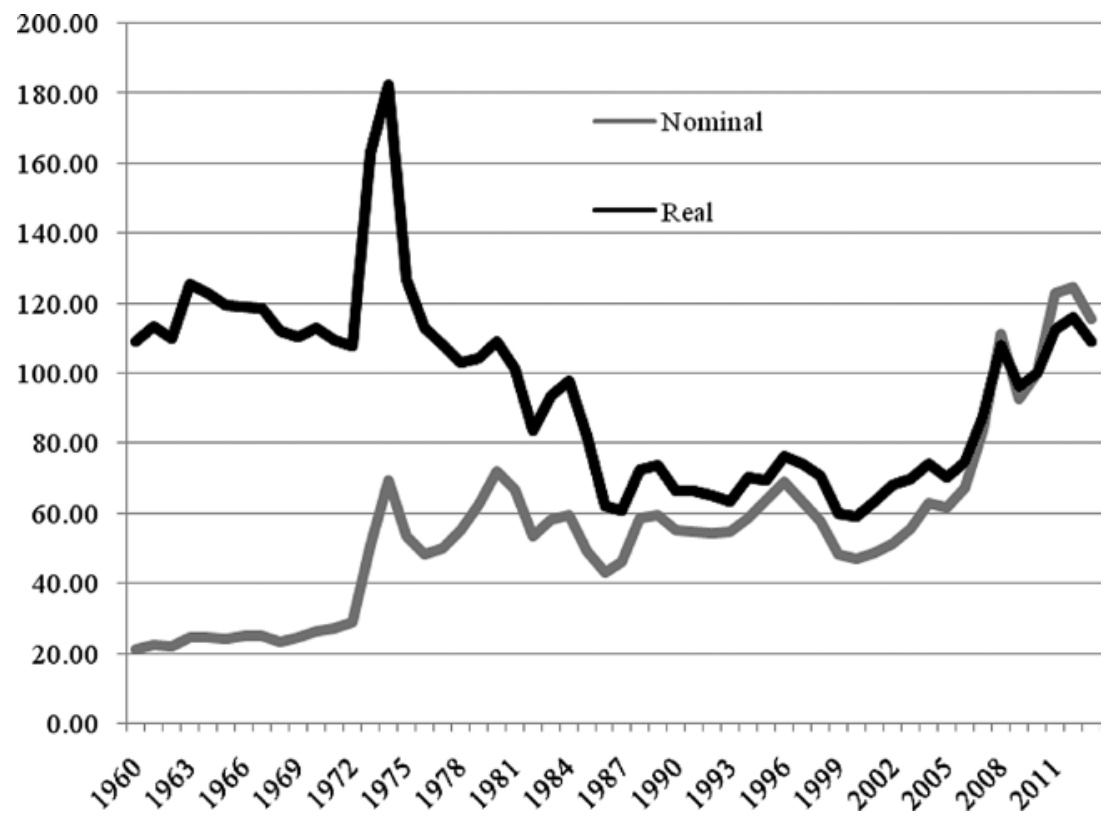

Source: US Dollars, Real Base 2000, World Bank Commodity Prices (Pink Sheet) 2013.

\section{Figure 1.4 World food price indices}

of 1973-75, a number of important international factors conspiring to generate major inflation. First, the collapse of the Bretton Woods exchange rate system in 1971 and the beginning of the era of floating exchange rates had seen a major depreciation of the value of the US dollar, in which most major commodities were priced in international trade. Second, the USSR chose in 1972 to combat yet another very poor domestic grain harvest by buying grain on the world markets (especially the US), rather than (as in the past) by slaughtering livestock to reduce feed requirements. No doubt it was encouraged to change its practice by the value of gold against the dollar, and also by the fact that the US was subsidizing grain exports at the time to reduce the substantial US Commodity Corporation's stocks. The unexpected Russian purchases were sufficient dramatically to increase world grain prices. Third, the oil embargo of the Organization of Petroleum Exporting Countries following the Yom Kippur war in 1973 led to the first oil crisis, prompting rapidly escalating oil prices. The consequent spike in world food prices is illustrated in Figure 1.4.

For the CAP, this meant that, for the first time, world prices actually exceeded the threshold prices. To protect the internal market from such rapid escalation of world prices, the apparatus of the CAP went into reverse - import levies became export taxes. For UK agriculture, the coincidence could hardly have been worse. The 'fact' that food prices would increase in the UK as a consequence of EEC membership had been the one thing on which all sides in the debates about prospective UK entry had agreed. Food prices, and all prices, certainly did increase very substantially following the UK's entry in 1973, but the cause was not the CAP or EEC membership: indeed, the UK's 
transition to the full provisions of the CAP did not happen until the end of the decade. Nevertheless, British agriculture responded to the increase in prices as if they were permanent (policy driven) rather than temporary, and investment in land, plant and equipment (the fixed costs of the industry) increased substantially and (so it proved) unsustainably.

\subsection{The Crisis Years}

By the end of the 1970s, the problem of surpluses, and consequent rapidly rising expenditure, had reappeared. However, radical reform of the policy was no closer to political acceptability than previously. Harvey, for one, argued that the CAP at this period appeared to be more of a stumbling block to cohesion than a cornerstone of the EU. ${ }^{17}$ This interpretation, based on an economic welfare analysis of CAP price support, was summarized in a comparison of the effects of the CAP on four major dimensions of national and citizen interest: the level of farm incomes; the change in farm incomes relative to the rest of the economy which could be achieved through changes in price support; consumer costs; and taxpayer costs. ${ }^{18}$ The rank order of the 'force' of these interests between and among the then Member States is shown in Table 1.1.19

The extent to which the competing interests in agricultural policy are harmonized within each Member State by the effects of the CAP can be identified by the correlation between the national interest rank and the rank of the effects of the CAP on this interest by country (the columns of Table 1.1). In general, the effects of the CAP on farm incomes and both consumer and taxpayer costs were broadly consistent with national interests in 1979, especially for Germany and the Netherlands. Even so, neither the UK nor Italy could be expected to be satisfied that the policy was clearly working well for them. However, a comparison of national interests and the effects of the CAP across the whole Community (the rows of Table 1.1) shows that the CAP was, if anything, contrary to the ranking of national interests, with specific reference to improving farm incomes and the impacts on consumer costs. Harvey concludes: ${ }^{20}$

... the comparison of likely national (regional) interests of the Member States in agriculture with the effects of this Commom Agricultural Policy ... strongly suggests that unification and integration of the Member States is not being served by the policy. Not only is this in spite of

17 D. Harvey, 'National interests and the CAP', (1982) 7 Food Policy 174.

18 See A. Buckwell, D.R. Harvey, K.J. Thomson and K. Parton, The Costs of the Common Agricultural Policy (Croom Helm, 1982).

19 The table shows rank orders between the Member States of the following measures: 1(a): Agricultural producer surplus generated by the CAP compared with free trade at world prices as a proportion of final agricultural production (1979); 1(b): Proportion of total GNP in agriculture proportion of total labour force in agriculture (1979); 2(a): Increase in agricultural producer surplus per head of agricultural labour force from a 10 per cent increase in common prices for all commodities; 2(b): as 1(b); 3(a): Increase in user costs (as measured by decline in consumer surplus) per unit increase in farm incomes following a 10 per cent increase in common prices; 3(b): Nonagricultural working population as a proportion of total working population; 4(a): Increase in tax contributions per unit increase in farm incomes following a 10 per cent increase in common prices; and, 4(b): GDP per head, 1978, in ECU.

20 Harvey (above n 17), 187. 
Table 1.1 National interests and the CAP (1979)

\begin{tabular}{|c|c|c|c|c|c|c|c|c|c|}
\hline & G & $\mathrm{F}$ & I & $\mathrm{N}$ & $\mathrm{B} / \mathrm{L}$ & UK & $\mathrm{Ir}$ & Dn & Corr. \\
\hline \multicolumn{10}{|l|}{ 1. Farm Income Level } \\
\hline a) CAP effects & 1 & 7 & 8 & 5 & 3 & 6 & 3 & 2 & \multirow{2}{*}{0} \\
\hline b) National interests & 1 & 3 & 2 & 6 & 7 & 8 & 4 & 4 & \\
\hline \multicolumn{9}{|l|}{ 2. Income Improvement } & \\
\hline a) CAP effects & 5 & 7 & 8 & 2 & 1 & 4 & 6 & 3 & \multirow{2}{*}{$-0.6^{*}$} \\
\hline b) National interests & 1 & 3 & 2 & 6 & 7 & 8 & 5 & 4 & \\
\hline \multicolumn{9}{|l|}{ 3. Consumer Costs } & \\
\hline a) CAP effects & 6 & 5 & 8 & 3 & 4 & 7 & 2 & 1 & \multirow{2}{*}{-0.17} \\
\hline b) National interests & 4 & 6 & 7 & 3 & 2 & 1 & 8 & 5 & \\
\hline \multicolumn{9}{|l|}{ 4. Taxpayer Costs } & \\
\hline a) CAP effects & 2 & 3 & 5 & 6 & 4 & 1 & 8 & 7 & \multirow{2}{*}{0} \\
\hline b) National interests & 2 & 5 & 7 & 4 & 3 & 6 & 8 & 1 & \\
\hline Correlation Coeff. & $0.8^{*}$ & 0.6 & 0.1 & $0.8^{*}$ & 0.3 & 0 & 0.5 & 0.3 & \\
\hline
\end{tabular}

Note: * Significantly different from zero at 95 per cent confidence level.

Source: D. Harvey, 'National interests and the CAP', (1982) 7 Food Policy 174, 186.

the common principles, in large measure it is because of the common principles. In this sense, the CAP serves member interests less well than some other differentiated (although communally agreed) policy. Continued adherence to the common principles may be seen as exacerbating the international conflict of interests and hence endangering the survival of the Community.

In addition, if the principal aim of the policy is to raise farm incomes, then the prospects for the future development of the policy were not good at this time. Those countries with the most interest in improving farm incomes (Germany, Italy and France - row 2b) were also those countries for which increasing the level of common price support under the CAP were least effective - row 2a. In fact, up to 1979, exchange rate variability between the Member States had resulted in a system of uncommon rather than common prices, through the use of 'Green Money'.

As Member State currencies appreciated or depreciated against the European Currency Unit, the European unit of account in which the common prices were fixed, so national support prices would vary. To avoid these largely unwanted effects, Member States were allowed to fix their 'green' exchange rate, and a system of Monetary Compensatory Amounts (MCAs) was used to tax and subsidize cross-border flows to bridge the gap between 'green' and market rates of exchange. Member States had some flexibility, under this system, to adjust their 'green' rates of exchange, though only towards market rates, so as to better harmonize the 'common' prices with their own national interests. The consequent pressures to raise common prices to achieve national farm income objectives 
may thus have been somewhat mitigated up to 1979. The introduction of the European Exchange Rate Mechanism in 1979 was intended to stabilize European currency fluctuations and might have been expected to remove at least some of this room for manoeuvre. However, Josling provides a more detailed account of the influences of exchange rates on the development of the CAP and points out that 'many of the later problems can be traced to the first few years of the CAP's existence in a volatile foreign exchange market' as common prices were ratcheted up (during the 1970s) to compensate German farmers from the price cuts that would otherwise have been imposed by appreciation of the Mark. ${ }^{21}$

\subsection{Producer Co-responsibility}

Since the option of reform of the policy towards lower levels of price support appeared politically impossible, the policy entered a phase of producer 'participation and co-responsibility' in the 1980s, through producer taxes (levies) on surplus production (sugar and milk) and 'prudent' increases in target prices (below inflation). ${ }^{22}$ However, butter and skimmed-milk mountains, in particular, continued to grow. The only possible alternative - limits on quantities produced and sold (quotas) - were practically inevitable, subsequently being introduced for milk in April 1984. Dairy farmers were allocated a quota, as a limit on the deliveries they could make to the relatively concentrated distribution and processing plants. A super-levy, approximately equivalent to the cost of surplus disposal on world markets, was charged on any deliveries in excess of the quota (applied in retrospect at the national level). A 'milk quota', as the license to sell milk at the supported price, thus became a necessary and valuable asset to dairy farmers. The implementation of the quota varied considerably between Member States, with some allowing free market exchange of quota from the outset (for example, the UK) and others (for example, France) only allowing exchange of quota through an official pool. Nevertheless, the value of the quota effectively captured the value of the price support to dairy farmers, with the prices of cows, milking equipment, buildings and land adjusted downwards as a result. In effect, new entrants to the dairy sector now had to pay for their support through the purchase price of the necessary quota, rather than, as before, in the value of dairy herds, equipment and land. ${ }^{23}$

The year 1984 also saw the climax of the controversy over the size of the UK's contribution to the EU budget ('Mrs Thatcher's Billion'). Since the majority of EU spending was still devoted to agriculture (see Figure 1.3 above) and since the UK was a relatively small agricultural producer, the UK's contributions to the budget (although very small in comparison to national spending) greatly exceeded her receipts of agricultural support, so the UK's net budgetary balance with the EU was heavily negative, by about $£$ lbillion.

21 T. Josling, 'External Influences on CAP Reforms: An Historical Perspective', in J. Swinnen (ed.), The Political Economy of the Fischler Reforms of the Common Agricultural Policy (CEPS, 2008), 57, 61 .

${ }^{22}$ Above n 16, 17.

23 See, e.g., D. Colman (ed.), Phasing out Milk Quotas in the EU, Report for the UK Department of Rural Affairs, Manchester University, April, 2002 (available at: http://archive.defra. gov.uk/evidence/economics/foodfarm/reports/documents/milkquota.pdf). 
After acrimonious and protracted negotiations, the Council finally agreed to provide a special rebate to the UK, at the expense of the other members.

\subsection{The First (MacSharry) Reform}

While quotas at least put a lid on the dairy surplus problem, the EU was still exporting considerable quantities of both dairy products and cereals to the world market in the 1980s, with the aid of substantial export subsidies. Not surprisingly her trading partners were becoming very irritated, as these subsidized exports were clearly undermining world prices. The members of the GATT initiated the Uruguay Round of negotiations in 1986, with the explicit intention of dealing with the growing problem of agricultural protection. The US, especially, was also suffering escalating costs of its own farm policies, based on non-recourse loans to producers, redeemable as and if products were eventually sold on the market. Otherwise, the loans were recovered by the US Commodity Credit Corporation taking ownership of the unsold stock at the loan rate per tonne. ${ }^{24}$ Since the loan rates effectively became the floor in the world markets for these crops, continued pressure on world prices was not at all in US interests. The Uruguay Round promised to provide some relief. However, the US and EU positions at the opening of the Round were diametrically opposed. The US wanted to eliminate all domestic price protection, while the EU envisaged some sort of world market sharing agreement. As a consequence, the negotiations made no progress. ${ }^{25}$

The CAP (and the EU) became even larger in 1986 with the Iberian enlargement to include Spain and Portugal, Greece having joined in 1981. By 1988, the EU's internal difficulties had become sufficient to persuade the protagonists (the Commission, Council and European Parliament) to adopt a longer term planning process, involving agreement to a five year 'financial perspective', principally focused on the increasing difficulty of curbing agricultural spending to provide resources for other Union activities, not least, regional development and a modest social fund. In addition, a new 'own resource' was added, based on Member State national income, to better reflect the income and wealth of the Member States than the VAT base. The agreement also introduced budget 'stabilizers', which limited the quantities which would be eligible for guaranteed support and placed a ceiling on total own resources of 1.2 per cent of EU GDP.

The Single European Act in 1987 changed the decision-making process significantly, by removing the need for unanimous agreement in the Council of Ministers and allowing for qualified majority voting to reach policy decisions. Henceforward, the Commission would not be so constrained in its proposals for reform as was the case when unanimous consent in the Council was required. ${ }^{26}$

24 For further information see, in the first instance, the US Office of the Federal Register (available at https://www.federalregister.gov/agencies/commodity-credit-corporation).

25 For discussion, see, e.g., K. Ingersent A.J Rayner and R.C. Hine (eds.), Agriculture and the Uruguay Round (MacMillan, 1994); and T.E Josling S. Tangermann, and T.K Warley, Agriculture in the GATT (MacMillan, 1998).

26 C. Crombez, 'Institutional Reform and Agricultural Policy Reform in the EU', in Swinnen (above n 21), 25. 
In 1989, the Berlin Wall collapsed. This 'earthquake' fundamentally altered both the contextual terrain and the political climate surrounding the CAP. Immediate absorption of East Germany into the EU was an inevitable consequence, and added to the strong political pressure to prepare for the absorption of siblings elsewhere in Central and Eastern Europe. The outcome was the agreement to Commissioner MacSharry's 1992 CAP reform package, incorporating, as far as cereals policy was concerned, two radical policy changes: first, the replacement of internally supported market prices with price reductions and (area-related) compensation payments; and, second, the requirement (for larger producers) to set aside land, and not plant it, in order to receive compensation payments.

The influence of the GATT negotiations in encouraging semi-decoupled compensation through area payments and set aside seems clear and is typically well acknowledged, including the assertion by the Commission that the new lower intervention price was set at a world free-trade level. ${ }^{27}$ While a strong supply control policy (presumably through set aside or similar form of area control) might have seemed a viable response to GATT pressure for CAP reform in the early stages of the negotiations, the lack of progress on a 'managed world market' agenda provided the Commission with strong signals that the GATT environment would not permit such an option to survive. Once this 'fact' had been assimilated, only two courses were then viable: an effective blocking of an agricultural agreement under the GATT (on the precarious assumption that other countries would eventually allow the rest of the agreement to go through without agriculture); or acceptance that internal market support prices would have to be reduced. The latter option required some form of compensation payment scheme to make it acceptable to the farm lobbies and their supporting governments and constituencies. It also seemed inexorable that this acceptance was substantially assisted (if not actually pre-conditioned) by the collapse of the Berlin Wall and the unification of Germany to include the substantial arable areas (and typically much larger farms) of the former East Germany, which (unlike Western Germany) had an obvious comparative advantage in arable farming.

Given the compensatory nature of the new area payments, it was a natural consequence that these payments should be linked to areas of cereals grown. The linking of payments to land can be explained as a 'natural' evolution from the previous market-based support system and an unwillingness of the political decision-makers to live with a complete decoupling of payments immediately. The inclusion of set aside in the package is more difficult to reconcile with most logical analyses of the policy options. However, within an evolutionary framework, this part of the reform can be seen as: first, mimicking an apparently acceptable policy option used by the other major negotiator (the US), and thus defensible within the GATT negotiations; second, a potential negotiating weapon, as evidence of the EU's willingness to make a 'down-payment' on the objective of stabilizing world cereal prices at a competitive level; and, third, a 'throwback' to the genotype

27 European Commission, COM (91) 258, The Development and Future of the CAP where it was stated that: '100 ECU represents the expected world market price on a stabilised world market', at 9. For discussion, see Josling, (above $n$ 21); and see also W. Coleman and S. Tangermann, 'The 1992 CAP Reform, the Uruguay Round and the Commission: conceptualizing linked policy games', (1999) 37 Journal of Common Market Studies 385. 
of supply control, countering the illogical but pervasive view that price reductions alone would not be sufficient to remove the surplus production problem.

CEE liberalization also appears to have been a strong influence, though this is not supported by reports of the policy-making decisions. ${ }^{28}$ However, it does seem clear that the only basis on which the CEE agriculture sectors could be admitted to an EU free-trade area without compromising the CAP was a reform to bring internal market prices closer to their free-trade world competitive levels. In addition, the substantial reduction in the internal EU price (so long as the EU remained on a net-export basis) was a necessary improvement as far as domestic EU considerations were concerned. The environmental damage of farming was becoming a forceful political argument in favour of reducing the incentive for intensive (high input) production techniques and allowing, if not encouraging, the 'development' of land use in more environmentally friendly ways, further supporting the set aside provision.

The Uruguay Round Agreement on Agriculture (AoA) was finally concluded in 1994 and within the WTO legislative framework brought into existence a substantial external constraint on future farm policy development. Henceforth, severely distorting price support was curtailed with explicit and binding international (WTO) limits. Furthermore, the EU's variable levy system was effectively outlawed, as all import taxes were bound as fixed tariffs rather than allowed to be variable. In addition, export subsidies were to be reduced both by volume and by expenditure, and then bound. However, 'direct payments' (such as the EU's area and similar headage payments for livestock producers), especially if divorced (decoupled) from current production decisions, were deemed under the AoA to be less distorting of world markets and prices, and hence were excluded from the WTO bound ceilings on support spending. The future trajectory of the CAP was now set towards such direct payments. As Josling comments, 'in effect, the MacSharry reforms rescued both the CAP and the Uruguay Round' ${ }^{29}$

By the early 1990s the proportion of the EU budget devoted to agriculture finally peaked (as a proportion of EU gross national income) and subsequently began a gentle decline (see Figure 1.3 above). The Maastricht Treaty on European Union was signed in 1992, establishing a common foreign and security policy, laying the groundwork for monetary union and introducing a Cohesion Fund to invest in infrastructure in the poorest Member States. The ceiling on own resources was raised to 1.27 per cent of gross national product (GNP). Sweden, Finland and Austria joined the Union in 1995.

\subsection{Central and Eastern European Enlargement and the Fischler Reforms}

The turn of the century saw the EU preparing to accept the entry of the CEE countries and providing significant levels of pre-accession assistance for this purpose. The financial perspective for 2000-06 was the first to be drawn up in euros and it focused on the assistance to the applicant countries. However, many Member States were also concerned

28 See, e.g., S. Tangermann, 'An Ex-post Review of the 1992 MacSharry Reform', in K. Ingersent A.J. Rayner and R.C. Hine (eds.), The Reform of the Common Agricultural Policy (Macmillan, 1998) 12.

29 Above n 21, 67. See also J. McMahon, The WTO Agreement on Agriculture: A Commentary (Oxford University Press, 2006). 
about stabilizing public expenditure, not least because of the fiscal discipline required to join the euro. As a result, agricultural spending was held stable and cohesion expenditure was refocused on areas of highest priority. The UK budgetary correction was retained, but a new mechanism reduced the share of Germany, the Netherlands, Austria and Sweden (the countries with the largest negative budgetary balances) in funding EU expenditure. Nevertheless, there was continuing severe pressure radically to reduce CAP spending, with a key factor being reduction of the cost of the impending CEE enlargement. ${ }^{30}$

'Agenda 2000' outlined the policy developments that would be necessary and included the establishment of a second pillar (Pillar II) of the CAP, devoted to rural development and environmental conservation. ${ }^{31}$ Importantly, the CAP principle of common financing was not applied to Pillar II spending, which required Member State co-financing, in common with most other European policies. Significantly, agri-environmental instruments were to be a compulsory part of the rural development programmes. The overall objectives of the reform included greater market orientation and increased competitiveness. Support prices were to be reduced (by 15 per cent for cereals and milk and 20 per cent for beef), but these reductions were to be gradually phased in and compensated with increases in direct payments. Significant assistance (€520 million per year) was provided under the SAPARD (Special Accession Programme for Agriculture and Rural Development) programmes to the new Member States (NMS) in Central and Eastern Europe, directed to helping the authorities in those countries in their preparation for EU entry. ${ }^{32}$

Although Agenda 2000 introduced the revised principles of the CAP, it did not much change the practice, except to commit to a 'Mid-term Review' of the policy in 2003. Prior to this review, the budgetary implications of enlargement, in particular, continued to cause major concern. The Council summit meetings in 2002 sought to clarify and constrain these implications. But the CAP proved its resilience against substantial budgetary pressure once again. It was agreed that the agricultural budget for market intervention and direct payments would be fixed in real terms at the 2006 level for the period 2007-13, while rural development spending would not be constrained by this ceiling. The apparent contradiction of maintaining agricultural support at 'Western' levels within a fixed budget, while extending the provisions to include ten NMS with very substantial agricultural sectors (for example, Poland) was 'solved' (in other words, postponed) by agreeing that direct payments would be phased in for these countries. In 2004, they would only receive 25 per cent of the EU payments, gradually increasing to the full payment rates only in 2013. The NMS were allowed, however, to top up these payments to 55 per cent in the first year, increasing to 100 per cent by 2010, with national payments and rural development funds, once again breaching the common financing principle (at least temporarily).

\footnotetext{
30 See generally, e.g., Swinnen (ed.), (above n 21).

31 See, e.g., http://ec.europa.eu/agriculture/cap-history/agenda-2000/index_en.htm for details and documents.

32 See, e.g., R. Ackrill, The Common Agricultural Policy (Sheffield Academic Press, 2000); and, for a more detailed review, see M. Georgieva, P. Cerna, D. Matteus, K. Kovacs, J. Hazners, T. Grosse and M. Stoian, SAPARD Review in Bulgaria, Czech Republic, Estonia, Hungary, Latvia, Poland and Romania (Center for Policy Studies (CPS), Budapest, 2005) (available at http://cps.ceu. hu/publications/joint-publications/sapard-review).
} 


\section{Research handbook on EU agriculture law}

The Mid-term Review generated change of the greatest significance. Thus, Olper has commented: ${ }^{33}$

The Fischler reforms of the EU's common agricultural policy (CAP) can be defined as among the most radical since its inception. The strong shift to decoupled farm support, the introduction of cross-compliance and the strengthening of rural development through modulation have to be viewed as substantial innovations of the CAP, introducing significant constraints on future policy choices.

The most obvious of the Fischler reforms for farmers was the introduction of the Single Farm Payment (SFP), essentially replacing the previous area and headage payments with a single payment per farm. Member States were allowed to determine the method of conversion, either on the basis of historical entitlements per farm or on the basis of regional average levels of payments, or a combination of the two. The preservation of farm support in such an apparently transparent form was remarkable in the face of a major decline in the perceived legitimacy of the CAP. A succession of food scares and crises in Europe during the 1990s, coupled with continuing and growing environmental concerns, and the ongoing restructuring of agriculture which reduced the numbers involved, had all very substantially eroded constituency, official and public support for the continued predominance of agriculture in the European budget. The two key provisions of the Fischler reforms which persuaded at least the Commission, the Council and the European Parliament to accept this package were: 'cross-compliance' and 'modulation' ${ }^{34}$

Under cross-compliance eligibility for the SFP was conditional on farmers complying with a series of measures relating to public, animal and plant health, the environment and animal welfare, together with an obligation to maintain all agricultural land in good agricultural and environmental condition. ${ }^{35}$ The modulation provision was to enforce a minimum transfer of funds from Pillar I (direct payments) to Pillar II (rural development). Member States were allowed some flexibility in the extent and implementation of this 'modulation' of direct payments, with voluntary modulation permitted over and above the compulsory rate of 5 per cent which would be reached through incremental increases by $2007 .{ }^{36}$ However, the Commission estimated that less than 3 per cent of total resources would be moved from Pillar I to Pillar II between 2008 and 2013. ${ }^{37}$ In fact, although the Commission

33 A. Olper, 'Constraints and Causes of the 2003 EU Agricultural Policy Reforms', in Swinnen (ed.), (above n 21) 83.

34 See, e.g., J. McMahon, EU Agricultural Law (Oxford University Press, 2007) 250-59.

35 For the original provisions, see Council Regulation (EC) 1782/2003 of 29 September 2003 establishing common rules for direct support schemes under the common agricultural policy and establishing certain support schemes for farmers and amending Regulations (EEC) No 2019/93, (EC) No 1452/2001, (EC) No 1453/2001, (EC) No 1454/2001, (EC) 1868/94, (EC) No 1251/1999, (EC) No 1254/1999, (EC) No 1673/2000, (EEC) No 2358/71 and (EC) No 2529/2001, [2003] OJ L270/1, Articles 3-5 and Annexes III and IV.

36 Ibid, Article 10. In the event, the UK was the only Member State which applied a voluntary modulation system, with the rate for England set at 12 per cent for 2007, rising to 13 per cent for 2008 and 14 per cent for the years 2009-12: see Common Agricultural Policy Single Payment and Support Schemes Regulations 2005, SI 2005/219, Regulation 11 (as amended by SI 2007/3182).

37 For the legislative provisions, see Commission Decision 2006/410/EC of 24 May 2006 setting the amounts which, pursuant to Articles 10(2), 143d and 143e of Council Regulation 1782/2003, are made available to the EAFRD and the amounts available for EAGF expenditure, [2006] OJ 
proposed at the commencement of the Mid-term Review that compulsory modulation should increase to 20 per cent, ${ }^{38}$ it may be reiterated that only 5 per cent could be achieved in the final agreement, following pressure from France. Importantly, as noted above, Pillar II spending requires national co-funding, while only Pillar I conforms to the original principle of common financing and is therefore wholly funded through the EU budget. This may well have militated against agreement by Member States to shift funds from Pillar I to Pillar II.

The Mid-term Review also resulted in some changes in market organizations, not least in the dairy and rice sectors. Dairy quotas were increased and rice support prices reduced, to be replaced with direct support and integrated into the SFP. However, apart from rice, there was no change in import protection, since the reductions in internal prices were not accompanied by any changes in the external tariffs, which remained particularly substantial in the case of dairy products. In the final analysis, the Fischler reforms were more presentational and practical than fundamental. The level of support to farmers hardly changed, although the delivery through the SFP certainly became more transparent, and hence vulnerable in the future. Nonetheless, an important financial discipline was also included in the reform - that in the event of a breach of the overall financial ceiling for the CAP, direct payments would be reduced, ${ }^{39}$ as indeed has happened. Nevertheless, as the $\mathrm{CEE}$ countries become eligible for the full rate of direct payments, the pressure on the budget ceiling would re-emerge.

\subsection{The 'Health Check' and Cioloș Reforms}

In November 2008, Commissioner Fischer Boel's 'Health Check' of the CAP was finally agreed. The main provision was to increase compulsory modulation of Pillar I funds to Pillar II by an additional 5 per cent by 2012 (as against 8 per cent initially proposed by the Commission), with a further 4 per cent added from all support payments over a threshold of $€ 300,000$ per recipient. ${ }^{40}$ In addition, set aside was abolished and milk quotas were further increased, to be eliminated by 2015, while remaining intervention purchase provisions were scaled down so as to be only active in times of crisis.

The negotiations on the new Multiannual Financial Framework (MFF) for 2014-20, which would pre-condition the further reform of the CAP over this period, proved even more arduous than usual. By reason of the ordinary legislative procedure applying to

L163/10; and Commission Decision 2008/787/EC of 3 October 2008 amending Decision 2006/410/ EC setting the amounts which, pursuant to Articles 10(2), 143d and 143e of Council Regulation (EC) No 1782/2003, are made available to the European Agricultural Fund for Rural Development (EAFRD) and the amounts available for the European Agricultural Guarantee Fund (EAGF) expenditure, [2008] OJ L271/41.

38 European Commission, COM (2002) 394, Mid-term Review of the Common Agricultural Policy, 22.

39 Regulation 1782/2003, (above n 35) Article 11.

40 Council Regulation (EC) 73/2009 of 19 January 2009 establishing common rules for direct support schemes for farmers under the common agricultural policy and establishing certain support schemes for farmers, amending Regulations (EC) No 1290/2005, (EC) No 247/2006, (EC) No 378/2007 and repealing Regulation (EC) No 1782/2003, [2009] OJ L30/16, Article 7. As a consequence, in 2012 the total rate of (compulsory and voluntary) modulation for English farmers was 19 per cent, while farmers elsewhere paid 10 per cent. 


\section{Research handbook on EU agriculture law}

agricultural matters under the Treaty of Lisbon, the European Parliament was granted greater powers on such matters than simply the right to comment. This reform in institutional procedures was widely expected to slow down the decision-making process and possibly to make the final decisions more inflexible, and so it proved. The new MFF was not adopted until December 2013, following two and half years of negotiation. In the words of the Council Press Release:

The MFF regulation enables the European Union to spend up to $€ 960$ billion in commitments and $€ 908$ billion in payments over the next seven years. This is $3.5 \%$ and $3.7 \%$ respectively less than under the MFF 2007-13, ensuring budgetary discipline for the EU and reflecting the particular budgetary pressure that Member States currently face at national level. ${ }^{41}$

However, as Matthews notes: ${ }^{42}$

... one consequence of the budget bargaining is to reverse, at least temporarily, the long-run decline in the share of CAP expenditure in the EU budget. The Commission's original draft budget foresaw a reduction in nominal spending in 2014 compared to 2013. In the negotiations, the Council sought to further reduce the Commission's draft budget proposal, while the Parliament sought to defend it. The net result is a reduction of around $6 \%$ (in nominal terms) in the total budget in 2014 compared to 2013 whether measured in terms of commitment appropriations (CA) or payment appropriations (PA). CAP expenditure is actually reduced by less than this (by 2 or $3 \%$ whether measured in CA or PA terms), with the result that the share of the $\mathrm{CAP}$ in the total EU budget rises to $41 \%$, whether measured in CA or PA terms.

How did the CAP fare in the final MFF agreement for 2014-20 compared with the 2007-13 period? Matthews observed that the answer is not easy. ${ }^{43}$ The official story is shown in Figure 1.5, which indicates an 11.3 per cent reduction in Heading 2 spending at 2011 prices. Heading 2 includes, as major items, Pillar I and Pillar II spending. These reductions allow the MFF to increase spending within the overall limit on own resources on Heading 1a (measures for increasing competitiveness and providing jobs), although reducing that under $1 \mathrm{~b}$ (economic, social and territorial cohesion). The European Parliament's Explanatory Note on the Council's Conclusions on the MFF indicates that Pillar I spending will be cut at 2011 prices by 13 per cent, while Pillar II spending will be reduced by 18 per cent, ${ }^{44}$ which agrees with the simple calculation of indicative 2020 spending as a proportion of 2013 spending at constant prices in the MFF data provided by the Commission's website. These data (Figure 1.5) indicate a reduction in Heading 2 spending on the same basis of 15 per cent.

Matthews, commenting on the Parliament's presentation, notes that this reduction is actually no more than is required as a consequence of the 2007-13 financial discipline,

41 Council of the European Union, Press Release 439 (2 December 2013), Council adopts the Multi-annual Financial Framework 2014-2020.

42 A. Matthews, 'CAP Budget Share Rises as Budget Deadlock Finally Resolved' (13 November

2013) (available at http://www/CAPReform.eu).

43 Ibid.

44 European Parliament, European Council Conclusions on the Multiannual Financial Framework 2014-2020 and the CAP: Note (European Parliament, DG for Internal Policies, Department B, Brussels, 2013). 
Comparison 2007-2013/2014-20

commitments in EUR million (2011 prices)

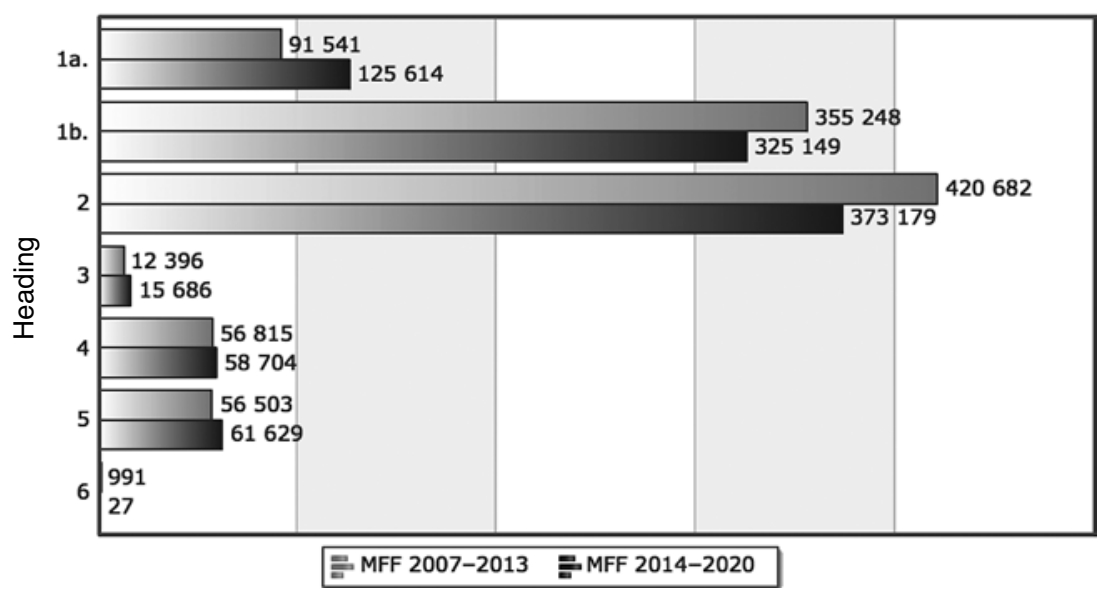

Note: $\quad$ EUR - Euros.

Source: European Commission, Financial Programming and Budget, Multiannual Financial Framework, http://ec.europa.eu/budget/mff/figures/index_en.cfm

\section{Figure 1.5 The 2014-20 Multiannual Financial Framework}

holding direct payments constant in nominal terms (and hence reducing in real, constant price, terms). He concludes: ${ }^{45}$

This outcome can be interpreted either as a triumph for the Ciolos strategy of legitimising Pillar I payments in this CAP reform, or as a shameful capitulation to the current beneficiaries of Pillar I payments and to those member states opposed to any meaningful CAP reform, depending on one's perspective.

On the other hand, he also notes, direct payments for the NMS were only being phased in during the 2007-13 period (and will continue to be phased in for Bulgaria and Romania until 2016 and now for Croatia since 1 July 2013). These commitments serve to increase the nominal spending on Pillar I. In addition, though, almost $€ 5$ bn has been removed from Heading 2 and allocated to different headings, which serves to mitigate the apparent decrease in spending. ${ }^{46}$

45 A. Matthews, 'The CAP Budget in the MFF Agreement' (3 July 2013) (available at http:// www/capreform.eu/the-cap-budget-in-the-mff-agreement/).

46 The Commission has been able to generate an additional cushion by several means to cope with this apparent shortfall. For instance, the Aid for the Needy scheme was moved into the European Social Fund under a different budget heading, saving $€ 2.5 \mathrm{bn}$. A further $€ 2.2 \mathrm{bn}$ was freed up by 'redefining' certain sanitary and veterinary spend outside the CAP budget and the EU's 'Globalisation Adjustment Fund' was extended to include farmers ( $€ 2.5 \mathrm{bn})$ so as to compensate for globalization-induced losses. Additionally, a $€ 3.5 \mathrm{bn}$ scheme, amounting to $€ 500 \mathrm{~m}$ for each year of the new budgetary period, forms an emergency reserve to address unforeseen problems 


\section{Research handbook on EU agriculture law}

The 2013 CAP reforms were negotiated under Commissioner Cioloṣ against this overall financial constraint and were formally adopted in December 2013. They followed intensive consultation (beginning in April 2010) and negotiations between the Commission, Council and European Parliament, ending with the political agreement in June 2013. ${ }^{47}$ The final agreement consists of four main regulations relating to: direct payments; rural development; horizontal measures; and the single common market organization, together with a transitional regulation for 2014. In the words of the Council Press Release, '[t]he main objectives of the reform are to make the CAP greener and better targeted, with a more equitable distribution of income support to farmers across the Union and a more effective rural development policy'. ${ }^{48}$

However, in the eyes of many commentators, the real objective was to defend and legitimize the continued spending of almost 40 per cent of the European budget on agriculture. ${ }^{49}$ The key to this objective was to 'green' the direct payments by making their receipt more dependent on the delivery of environmental benefits. The extent to which this is even feasible on a Europe-wide basis is debatable, but the provisions are that 30 per cent (only) of direct payments will be payable on condition that, as a general rule, farmers grow at least three different crops on their arable land, maintain a minimum area of permanent grassland and preserve areas and landscape features with a particular ecological value (termed 'ecological focus areas'). ${ }^{50}$ In the event, Member States are given considerable flexibility in their implementation of these provisions. For example, the grassland minimum area provision will be applied at the 'national' level in England, while the precise definition of ecological focus areas, which only applies to arable land, is just emerging. ${ }^{51}$ In any event, the actual contribution of the 'greening' provisions to the environmental and ecological condition of the Union's rural land is highly contentious. Many commentators argue that Pillar II targeted payments and programmes are much more likely to generate

linked to climate change, market crises and other threats to farming and food production capacity. This allows the Commission to reduce its traditional market management spending under Pillar I, allowing Pillar I to be devoted exclusively to direct payments (both the emergency reserve and 'Globalisation Adjustment Fund' being outside the CAP). In short, these 'accounting' redefinitions provide the CAP budget with enough 'headroom', in spite of a notional freeze, to cope with increased direct payments, especially to the NMS

47 See Europa website at http://ec.europa.eu/agriculture/cap-post-2013/ for documentation on these consultations and negotiations; and see, in particular, European Commission, MEMO/13/621 (26 June 2013), CAP reform: an explanation of the main elements.

48 Council of the European Union, Press Release 582 (16 December 2013), Common agricultural policy: the reform is approved by Council.

49 A. Matthews, 'A Triumph for the Irish Presidency: A Damp Squib for CAP Reform' (27 June 2013) (available at http://www.CAPReform.eu).

50 Regulation (EU) 1307/2013 of the European Parliament and of the Council of 17 December 2013 establishing rules for direct payments to farmers under support schemes within the framework of the common agricultural policy and repealing Council Regulation (EC) No 637/2008 and Council Regulation (EC) No 73/2009, [2013] OJ L347/608, Articles 43-7.

51 See Department for Environment, Food and Rural Affairs (DEFRA), Consultation on the Implementation of CAP Reform in England: Summary of Responses and Government Response (December 2013); and DEFRA, The New Common Agricultural Policy Schemes in England: August 2014 Update Including 'Greening: How it Works in Practice' (August 2014). 
environmental improvements than 'blanket' provisions under Pillar I. ${ }^{52}$ However, the agreement also includes a further modulation provision for Member States to transfer up to 15 per cent of their Pillar I spending envelopes into Pillar II. ${ }^{53}$ Although for England the full transfer was proposed, consultation resulted in a 12 per cent transfer, at least until 2016, when the full permitted 15 per cent transfer will be reconsidered.

A distinct feature of the Cioloș reforms is the amount of Member State discretion (flexibility) allowed in the implementation of the regulations, especially in the ways in which the direct payments are implemented. However, the agreement stipulates that all Member States should rebalance direct payments per hectare so that, as a general rule, any payment is at least 60 per cent of their national or regional average payment by $2019 .{ }^{54}$ There is also an agreement to move (slightly) towards a more equal ('equitable') distribution of direct payments across Member States. The politically contentious issue of harmonizing direct payment rates across all Member States proved, not surprisingly, to be too difficult to allow any substantial progress to be made during this reform, though it was certainly put on the formal agenda for the first time.

On the other hand, the negotiations took place during a time of heightened concern about the future of world food supply-demand balances and the experience of successive food price spikes (see Figure 1.4 above). The resulting pressure to re-connect support to production in response to supposed threats to food security was largely resisted, although there is some increased scope for Member States to use voluntary coupled payments (payments linked to production), subject to Commission approval (and to compliance with the EU's WTO commitments). ${ }^{55}$ Nevertheless, sugar quotas (supply management) are to be eliminated in 2017, the decision to end dairy quotas was upheld and proposals to increase intervention prices were resisted. ${ }^{56}$ The outcome of the post-2013 CAP negotiations is disappointing if compared with most of the objective analysis of the policy, more specifically the continued legitimacy of direct payments. However, regression to more interventionist and market distorting policies has been prevented.

\section{THE CHANGING SHAPE AND SHARE OF CAP PROTECTION AND SUPPORT}

A common measure of protection afforded to the agricultural sector is the Nominal Rate of Assistance (NRA). Essentially, this measures the gap between world prices of farm commodities and the domestic or internal price of these same commodities, expressed as a ratio of world prices to domestic prices. Thus, the NRA is zero only when there is no protection of domestic prices (or other support) to the farm sector. Otherwise, the value of the NRA measure shows the extent to which the domestic sector is protected and supported.

\footnotetext{
52 See, e.g., D. Harvey and A. Jambor, 'What role for public goods in the CAP?' (AES Conference, April 2013) (available at http://ageconsearch.umn.edu/handle/108957).

53 Regulation 1307/2013, (above n 50) Article 14.

54 Ibid, Article 25.

55 Ibid, Articles 52-5.

56 A. Matthews, 'The Ciolos CAP Reform' (17 December 2013) (available at http://www. CAPReform.eu).
} 


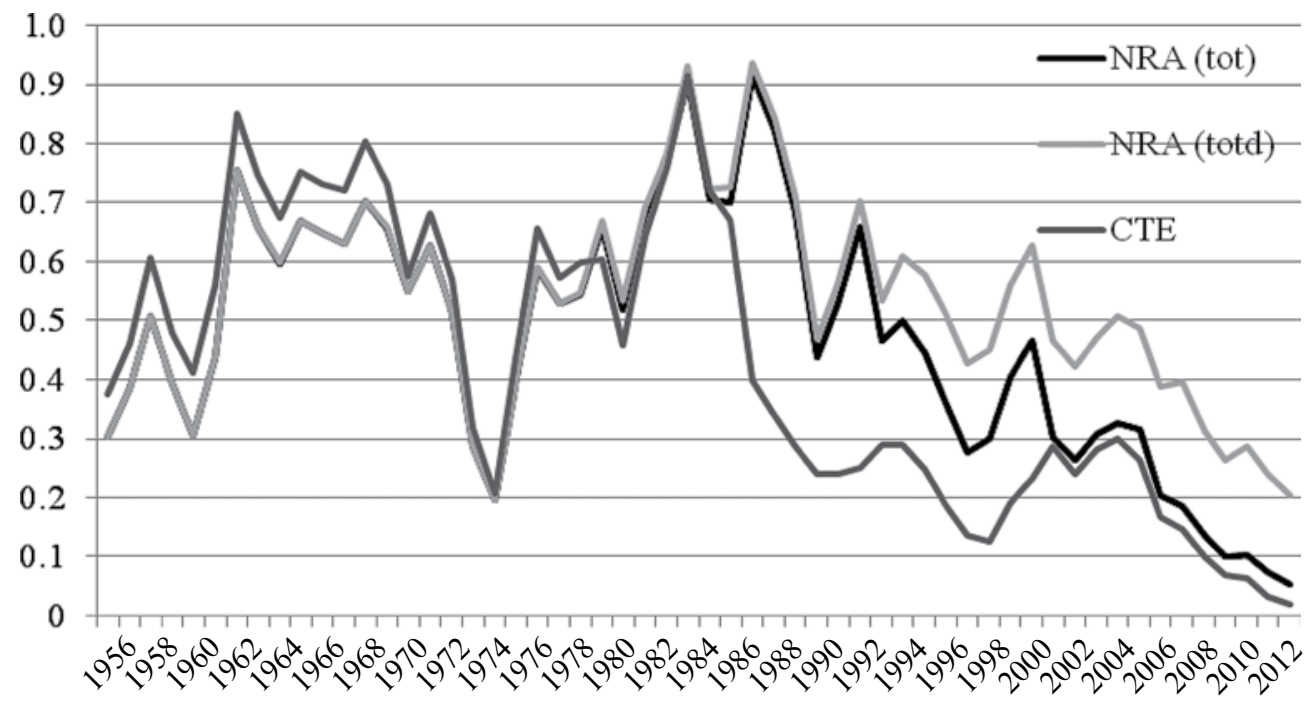

Source: K. Anderson and E. Valenzuela, World Bank Agricultural Distortions Database (World Bank, 2013) (available at http://go.worldbank.org/XIRCP7AUG0).

Figure 1.6 EU protection rates, 1956-2012

Figure 1.6 shows the history of the European NRA since the formation of the Community. This figure also includes an equivalent measure of the consumer cost of the policy - as the Consumer Tax Equivalent (CTE) - showing the extent to which domestic food prices are above prevailing world market prices (which might rule in the absence of support policy). ${ }^{57}$

The escalation of support at the inception of the CAP is clearly seen in Figure 1.6, as is the close correspondence between the CTE and NRA: the early days of CAP support were entirely financed by the consumer, to the extent of providing the EU budget with additional funds (own resources) through import levies. The massive world food and commodity price spike in 1973-75 clearly reduced both the CTE and NRA, interrupting an apparent political economy equilibrium at between 60 and 70 per cent rates of assistance and corresponding taxation. However, growing surpluses, both in the EU and elsewhere in the world, together with depressed world prices, escalated protection and tax rates to 90 per cent in the early 1980s, and coincided with the opening of the GATT Uruguay Round negotiations aimed at resolving the world market.

The early 1990s, following the MacSharry reform in 1992, clearly marked a major turning point in CAP protection rates, for both internal and external reasons. The MacSharry decoupling of support from production (and world prices) required a new measure of the rate of assistance to include direct payments (NRA (totd), in Figure 1.6),

57 In the absence of market price support in the EU, however, world prices would be expected to be higher, so both the NRA and CTE are exaggerated measures of the effects of the policy, being even more exaggerated for policies which are even more distorting of market signals, as in the early days of the CAP. 


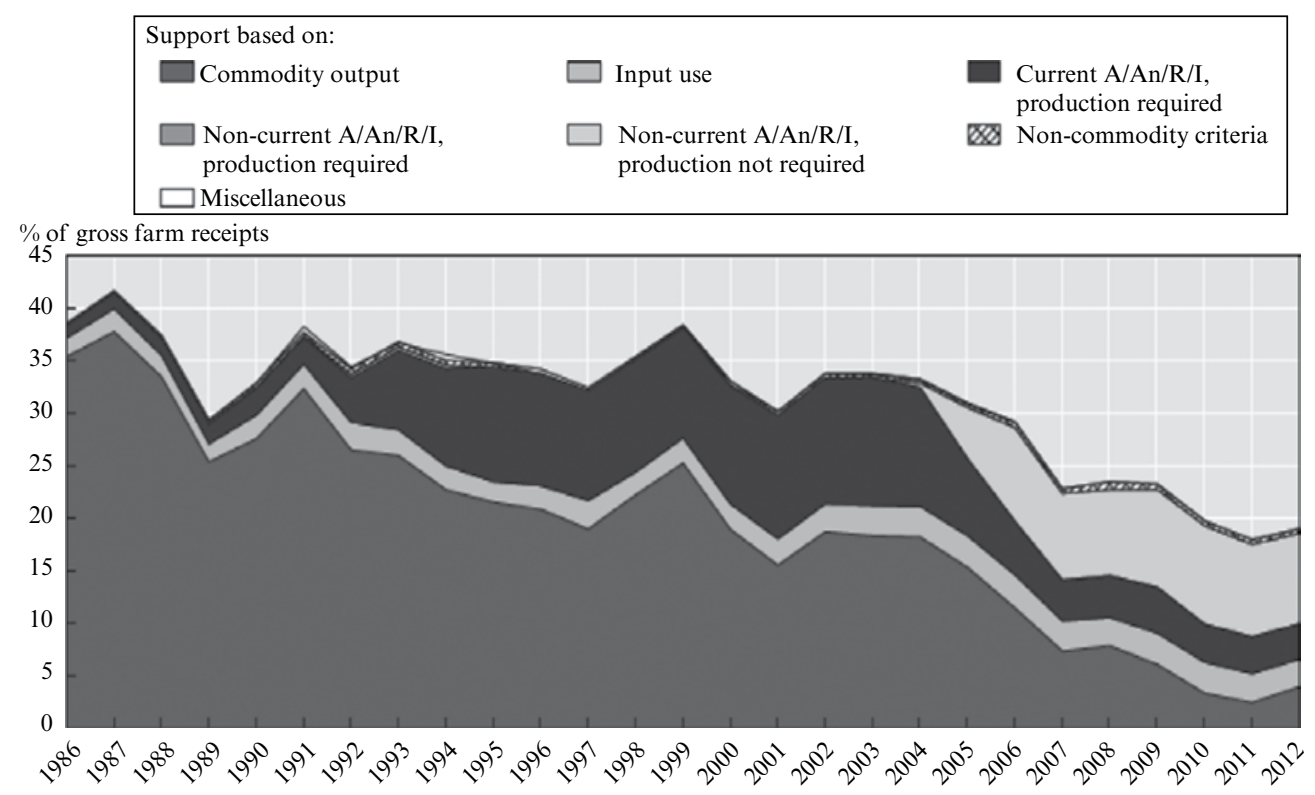

Note: EU12 in 1986-94 including ex-GDR from 1990; EU15 in 1995-2003; EU25 for 2004-06; EU27 from 2007.

Source: OECD, Agricultural Policy Monitoring and Evaluation 2013 (OECD, 2013), Chapter 9, European Union, Figure 9.1.

Figure 1.7 EU PSE level and composition, 1986-2012

which can be compared with the base rate of assistance which excludes direct payments (NRA (tot), in Figure 1.6). As can be clearly seen, both rates of assistance have fallen substantially since 1992, albeit with various spikes reflecting depressed world prices (and by the same token falling to close to zero by the end of the period as world prices strengthened). As a consequence, the European budget (taxpayers) are now funding CAP support through direct payments (NRA (totd)) to the extent of 20 per cent of world prices.

An alternative way of measuring the extent of agricultural support is the Producer Support Estimate (PSE), calculated annually by the OECD. ${ }^{58}$ In contrast to the NRA, the PSE measures support (both market prices and direct and other payments) as a proportion of gross farm receipts (including support) in each country or region, rather than as a proportion of prevailing world market prices. The recent history of the EU's PSE is shown in Figure 1.7. ${ }^{59}$ Since 1986, the rates of support in the EU as measured by the PSE have fallen from almost 40 per cent of gross farm receipts to little more than 20 per cent, with the major reduction beginning at the turn of the century. In addition, the changing composition of support is also clearly illustrated in this figure. The OECD

58 OECD, The PSE Manual (OECD, 2009).

59 OECD, Agricultural Policy Monitoring and Evaluation 2013 (OECD, 2013), Chapter 9, European Union, Figure 9.1. 
categorizes support measures according to whether or not receipt of support is dependent on output or is based on areas (A), animal numbers (An), receipts (R) or income (I), either in the current period or some historic (non-current) period, and also on whether or not current production is required for receipt of support. ${ }^{60}$ As Figure 1.7 shows, the support dependent on output (essentially market price support measured against prevailing world prices), which is the most distorting of world markets, has declined substantially from being the predominant form of support in the 1980s, to less than 5 per cent of current support. The slight increase in 2012 over 2011 is a reflection of the recent fall in world prices.

The MacSharry reforms in 1992 clearly resulted in the substitution of area and headage payments for market price support, while the Fischler reforms in 2003 further substituted direct (Single Farm) payments (Non-current A/An/R/I, production not required) for area and headage payments. These direct payments now make up half of the PSE measure of CAP support, and are regarded by the WTO as essentially non-distorting and therefore not subject to bound constraints. Similarly, the OECD also calculates a Consumer Support Estimate (CSE), as a percentage of farm receipts paid for by consumers through higher prices than the prevailing market price. In 1986-88, the CSE for the EU stood at 36 per cent, declining to 2 per cent in 2011 (with a slight increase to 4 per cent in 2012). ${ }^{61}$

The same story is reflected in the actual EU budget expenditure pattern on the CAP (Figure 1.8). This figure shows the decline in export subsidies (now effectively eliminated except under crisis conditions) and other market support in favour, first, of coupled (area and headage) payments and, since 2006, of Single Farm (decoupled) payments. While the total expenditure has risen, in constant price terms, from $€ 30$ billion in 1980 to more than $€ 50$ billion today, the share of the budget (and of EU GDP) has declined, as the Union has expanded and grown, from a peak of 0.65 per cent of GDP in the late 1980s and early 1990s to 0.43 per cent today: indeed, the proportion fell from more than 70 per cent of total EU expenditure in 1985 to 45 per cent in 2011. The financial discipline, which continues throughout the MFF 2014-20 period, effectively holds the support payment spending constant in nominal terms, while the 'modulation' of Pillar I funds to Pillar II is barely discernible in Figure 1.8, because of increasing EU budget spending on direct payments in the NMS.

\section{ISSUES AND PROBLEMS FOR THE FUTURE}

\subsection{General}

The critical issue which continues to face the CAP and its financing is the perceived legitimacy of direct payments to farmers, especially in times of apparently stronger food prices on the one hand and continued austerity for public budgets on the other. Numerous views have been expressed on the future of the CAP, especially during the consultation

60 Above n 58, 25.

61 Above n 59, Chapter 9, European Union, Table 9.2. 


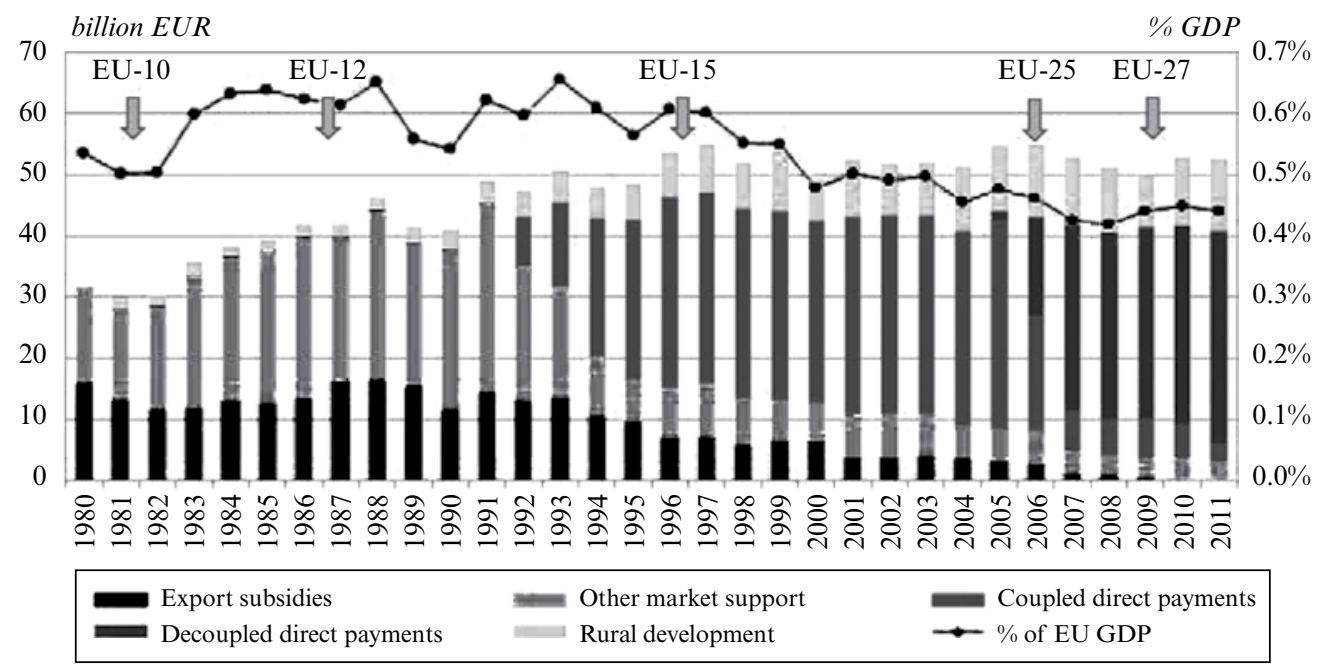

Note: $\quad$ EUR - Euros.

Source: European Commission, CAP Post 2013 (European Commission, 2013), Key Graphs and Figures, Graph 2

Figure 1.8 CAP expenditure, 1980-2011 in constant 2007 prices

process leading up to the Cioloș reforms. ${ }^{62} \mathrm{~A}$ comprehensive review of these contributions reveals that the critical ideas for reform still largely echo the 1997 Buckwell Report, ${ }^{63}$ reflecting the accepted economic logic that direct payments are inefficient and obsolete. ${ }^{64}$ Why does the EU need to continue to pay farmers from scarce tax revenues? The Cioloș answer appears to be that farmers need continued support in order to recompense them for their contribution to the rural environment and society. This argument is, however, substantially incoherent, and therefore ultimately unsustainable, on three major grounds.

First, EU-wide common 'greening' provisions are widely recognized as being virtually meaningless as effective instruments to encourage and reward care for the natural environment, which demands local and regional design and implementation. Second, the rates of payment bear no discernible relation to either the costs or the benefits of caring for the natural environment. Indeed, they cannot, since these rates derive from previous market price support levels and associated area and headage payments, albeit somewhat moderated by a move away from historic support 'entitlements' to regional payment rates based on agricultural area, as, for example, in the NMS. The levels of support, determined

${ }^{62}$ As an example, see the presentations and papers provided for a workshop of the Bureau of European Policy Advisors, Reflections on the CAP from a Long-term Perspective (Brussels, 26 February 2009).

63 European Commission, Towards a Common Agricultural and Rural Policy for Europe (DG VI/A1) (Report of an Expert Group (the Buckwell Report), 1997).

${ }_{64}$ See A. Jambor and D. Harvey, 'CAP2020: Literature Review of Challenges for CAP Reform', CRE Discussion Paper, Newcastle University, 2010. 


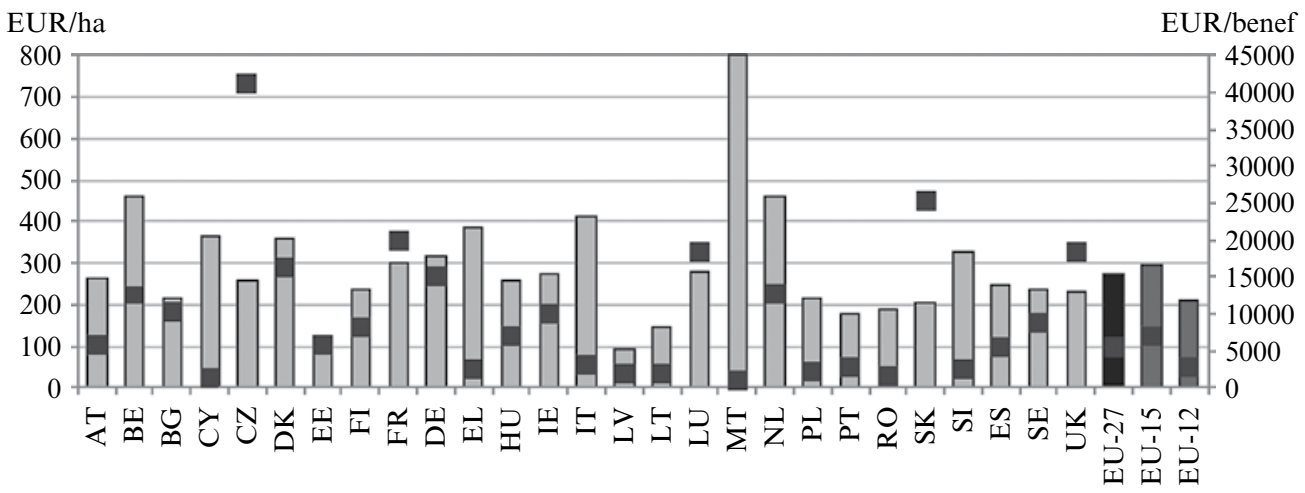

$$
\square \text { EUR/ha } \quad \text { EUR/beneficiary }
$$

Note: EUR - Euros; the hectare figure is based on the national envelopes of Member States after full phasing-in of direct payments in the EU-12 and the number of potentially eligible hectares under the Integrated Administration and Control System for 2008.

Source: European Commission, SEC (2011) 1153, Impact assessment: Common Agricultural Policy towards $2020,29$.

\section{Figure 1.9 Average direct payments per hectare and per beneficiary}

by the mix of commodities produced and their separate support levels, are not directly related to either the scarcity and hence value of environmental attributes or to the costs of conserving or improving these attributes. ${ }^{65}$ Third, and related, the rates of payment (either per hectare or per recipient (Figure 1.9) or as a proportion of agricultural valueadded (Figure 1.10)) vary greatly across the Community. This wide variation appears obviously inconsistent with the founding CAP principle of a common, unified market. Furthermore, the principle of common financing of the direct payments, stemming from the need to commonly finance export subsidies and treat import levies as own resources, is incoherent with the largely regional and national impacts and effects of either environmental or farm income support.

There is wide recognition of these evident inequities and the apparent need to reduce them. Indeed, the Commission's own Impact Assessment states: 'thus the main challenge stemming from the evaluation of Pillar $I$ is the need to redistribute support in a more effective and equitable manner, both among and within Member States' ${ }^{66}$ Yet, this is rather different from the political economy of doing much about it. As the Commission also noted:

both the options of granting a uniform flat rate direct payment across the whole EU and of basing the distribution of support on purely objective criteria reflecting the dual role of the

65 See, e.g., D. Harvey, 'Agri-environmental relationships and multi-functionality', (2003) 26 The World Economy 705.

66 European Commission, SEC (2011) 1153, Impact assessment: Common Agricultural Policy towards 2020, 28. 


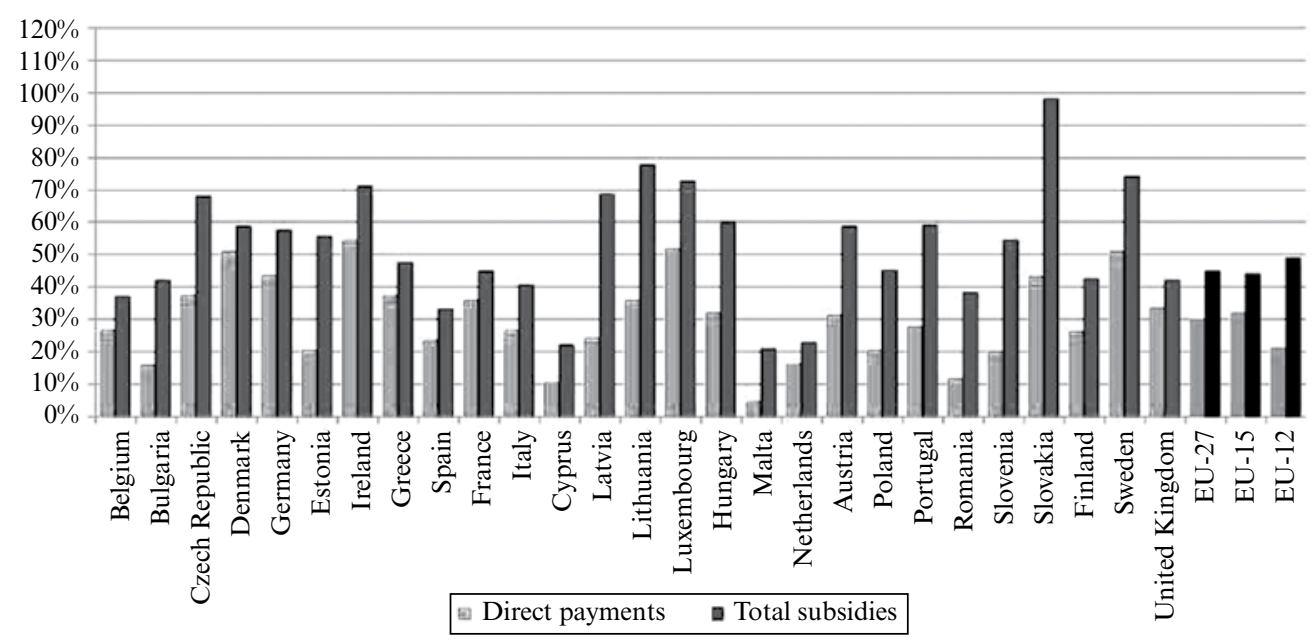

Source: European Commission, CAP Post 2013 (European Commission, 2013), Key Graphs and Figures, Graph 4.

Figure 1.10 Incidence of support as proportion of agricultural value-added

instrument (income support and environmental public goods) would lead to a significant redistribution of funds between Member States, the extent of which would depend on choice of criteria. The resulting impacts on incomes are also substantial. ${ }^{67}$

There are two major problems with this statement relating to the issue of the distribution of direct payments: first, the appropriate definition of 'purely objective criteria'; and, second, the political economy difficulties of achieving any majority consensus on how to redistribute funds between farmers and countries, especially within the constraint of an overall limit on the total budget.

\subsection{Objective Criteria for Distribution of Direct Payments?}

There is no such thing as an 'objective' distribution of direct payments. In the first place, it is well established, following Tinbergen, that meeting a number of different policy objectives or targets requires at least as many policy instruments as there are objectives. ${ }^{68}$ It is quite impossible to achieve both (many) environmental objectives as well as a (typically unspecified) farm income objective with a single instrument - the direct payment.

Supposing that the primary objective of the direct payments remains that of income support (as apparently still maintained by the Commission), it is clear that there would need to be an even more radical redistribution of present Pillar I payments to achieve any 'objective' definition of an income support target. The 2013 distribution of direct payments per head (person employed in agriculture) actually rewarded those already

67 Ibid, 48 .

68 J. Tinbergen, Economic Policy: Principles and Design (North Holland, 1956). 


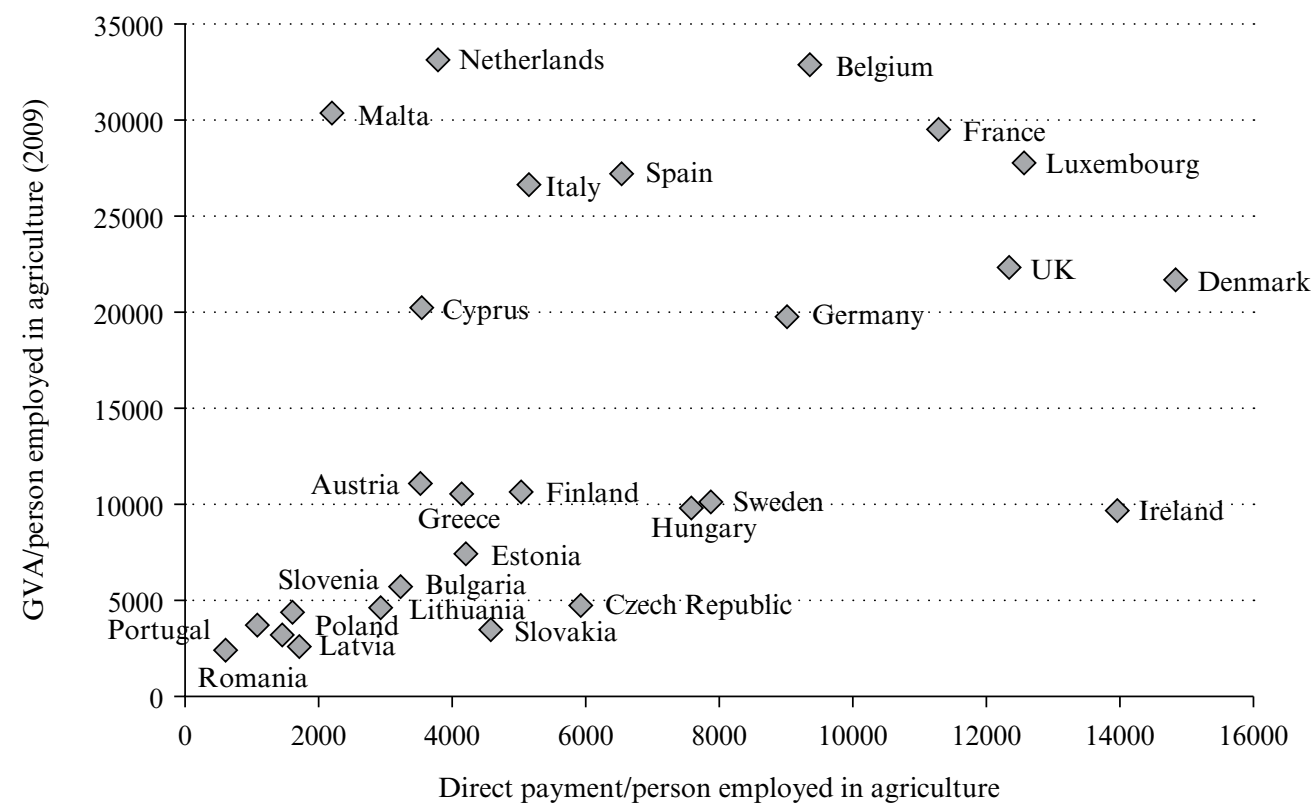

Note: Direct payments per head calculated on a 2013 basis, when current rates were fully paid by the EU in the NMS.

Source: Compiled from various European Commission statistical sources.

Figure 1.11 Average direct payments and GVA per person employed

earning greater factor incomes (gross value added (GVA)) per head (Figure 1.11), with a correlation coefficient of +0.5 . The more is earned per head, the greater the direct payment per head across the EU, as is also the case within each Member State, which is exactly opposite to any sensible interpretation of income support. Of course, direct payments themselves inflate GVA in agriculture. Subtracting the 2013 levels of direct payments from the GVA in Figure 1.11 (to produce an 'unsupported GVA') very substantially flattens the distribution of Member States towards the horizontal axis, and reduces the correlation coefficient to +0.08 . Nevertheless, a very considerable redistribution of payment rates would be necessary to reward or support those countries with low incomes (GVA) per head.

Nonetheless, it might be argued that the absolute level of factor incomes in agriculture is not the appropriate criterion for income support. Following the spirit of the political economy explanations for farm support at the beginning of this chapter, the agricultural earnings gap - the difference between factor incomes in agriculture and those in the rest of the economy - might be a more appropriate indicator of the 'need' for income support. Figure 1.12 shows the 2013 relationship between direct payments per head and this earnings gap. The slight correlation $(+0.2)$ clearly reflects the outlier (Luxembourg); otherwise the current distribution of direct payments across the EU bears no relation to the average income differentials between agriculture and the rest of the economy. 


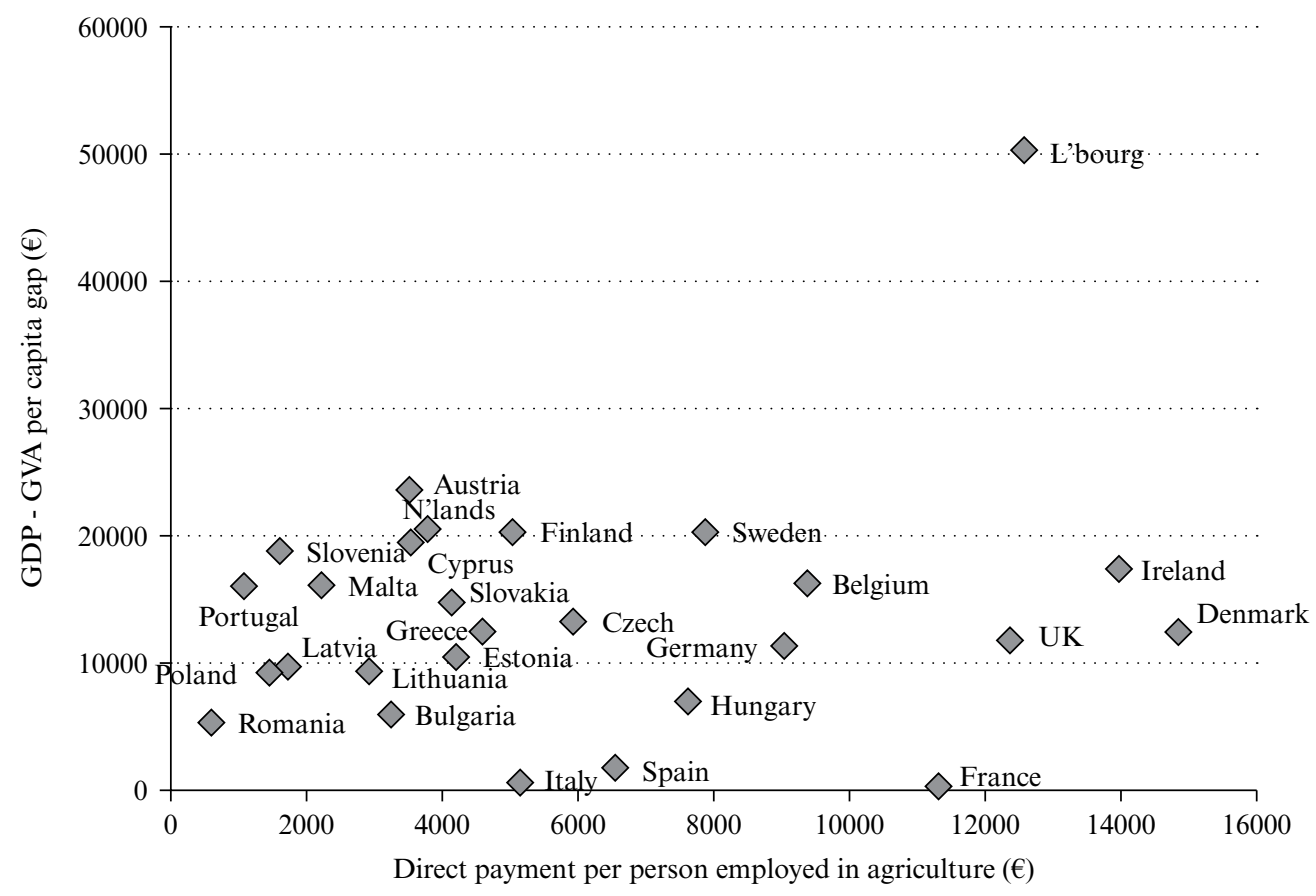

Source: Compiled from various European Commission statistical sources.

Figure 1.12 Correlation between direct payment per head and agricultural earnings gap

In any event, such crude, average aggregate measures of income difficulties and disparities hardly provide a coherent guide to the need for income support, while the present key (farm area) determining the level of farm payments is clearly quite contrary to any equitable form of distribution.

\subsection{Income Support?}

It should be obvious that the history of the CAP demonstrates clearly that the de facto intention of the policy has never been to support individual farmers' incomes, still less to support those with low incomes in farming. Price support, delivered on the basis of production, necessarily provides greater rewards to larger farmers than to their smaller peers. De jure, the intention of the CAP has not been (as is frequently asserted) a social policy. This should be evident from the statement of the first two objectives of the CAP, which make it clear that incomes in agriculture can and should be increased through increasing agricultural productivity and promoting the rational development and optimum utilization of factors of production, in particular labour (in other words, structural adjustment and increased output per labour unit). Only thus will a fair standard of living be ensured for the agricultural community. The necessary structural adjustment of the sector towards fewer and larger farms, employing less labour, was clearly recognized by the principal architect of the policy, Mansholt, as the only sustainable way of improving income in 
agriculture. Price support, and hence all derivatives of that support, including the direct payments, were supposed only to be a means towards this end, not the direct vehicle for income support. Neither economic logic, nor the historical evidence of agricultural support, supply any grounds for supposing that subsidization can directly improve farm incomes.

Incomes in farming are determined by what labour employed in farming might otherwise earn elsewhere. If incomes are higher in other activities, then labour can and should be expected to migrate to other occupations. Subsidizing the revenues of an effectively competitive sector can only result in increasing the demand for the fixed factors of the sector, principally land in the case of agriculture, and increasing their value and hence their prices. This can only increase the costs of farming. Tying subsidies directly to land ownership and/or operation can only reinforce this necessary connection. Direct payments can only result in higher land prices, to the benefit of the current owners. Incoming farmers necessarily find that the costs of entry to the business are increased to account for the present and expected future stream of support payments. Demonstrating this necessary connection empirically is difficult, if not impossible, because the workings of the land market are confused and disguised, not only by different institutional arrangements, but also by the myriad of other factors which influence land prices and rents, such as security of tenure, tax considerations (especially inheritance tax provisions (as in the UK)), specific contextual market conditions for product prices and input costs and so forth. Nevertheless, the logic is inescapable. Direct payments, in providing everyone with something to stand on, do not result in anyone seeing any better.

The apparently common and pervasive idea that the purpose of CAP support is to support farm incomes, and by implication, especially to support the incomes of poorer farmers, is clearly and unequivocally both de facto and de jure misguided. It is not and cannot be. The successive reforms of original price support to current direct payments, beginning with MacSharry in 1992, could not and have not altered this fundamental fact. The only economically coherent and thus sustainable argument in favour of agricultural support is that the support should assist, if not actually encourage, the structural and technological adjustment of the industry to enable those remaining in it to enjoy incomes comparable with the rest of the economy. Reform of the original price support system (which arguably did encourage and assist this adjustment) into a land-based but decoupled system of direct payments almost certainly means that this assistance is substantially reduced. In fact, it is likely that the necessary structural adjustment is impeded by this system of support, since the costs of expansion are increased, and the rate of outflow reduced from what it would otherwise be. The logical and evidential conclusion is that the notion of direct payments supporting farm incomes should be very substantially revised or eliminated.

These arguments also illuminate the apparent contradiction between, on the one hand, internal EU concerns that demonstrably uncommon rates of payment distort competition within the Union and, on the other hand, the fact that the EU continues to maintain that direct payments do not distort international markets. Direct payments clearly affect and thus distort markets if they affect farm employment and investment decisions, and hence affect farm structures and their productive capacities. However, the direction of these distortions is unclear. More people and capital in the sector do not necessarily mean that the industry is more competitive than otherwise, the more so if the injection of additional 


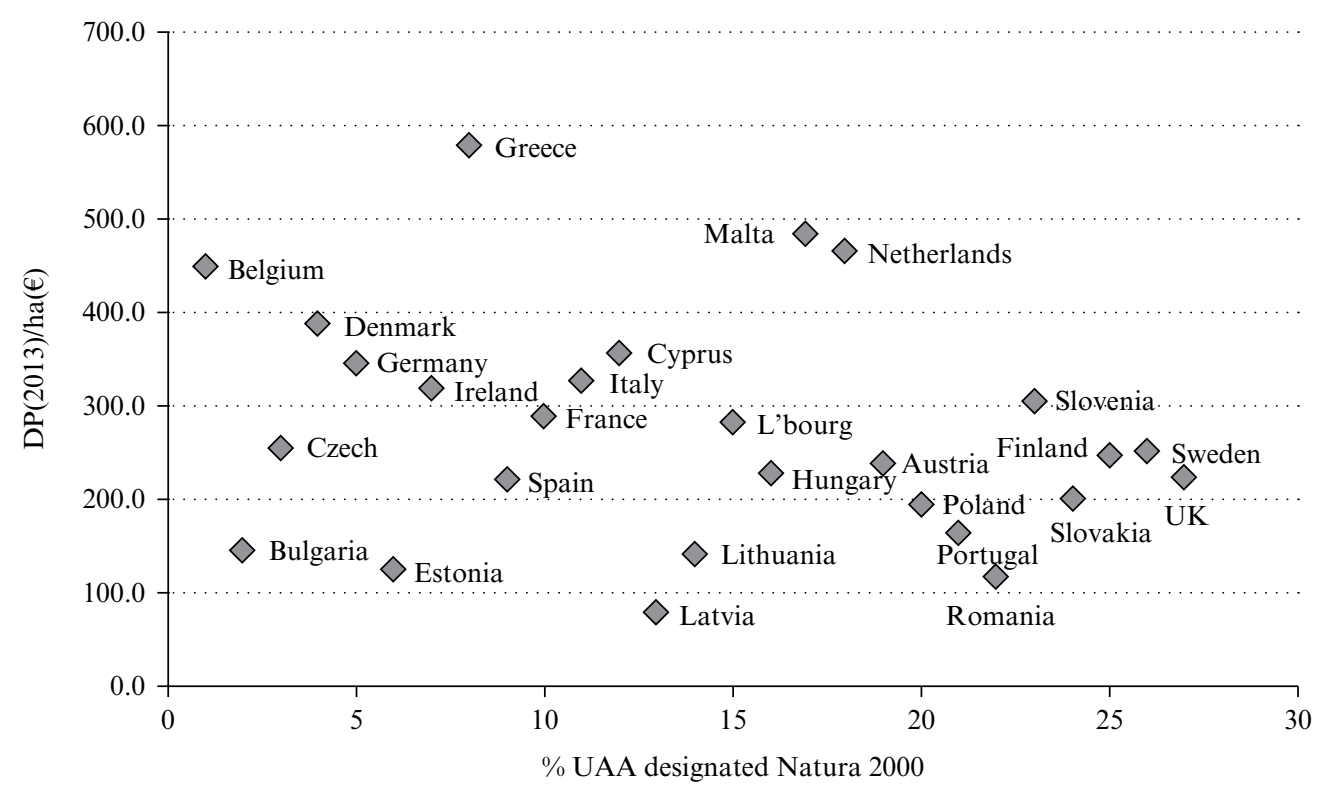

Source: European Commission, Indicators for Rural Development Report (European Commission, 2010) Table 2.2.4.6.

Figure 1.13 Correspondence between direct payments and Natura 2000 UAA

funds discourages structural adjustment towards more economically optimal structures and more rapid adoption of new technologies.

\subsection{Environmental Conservation?}

The remaining argument in favour of retaining direct payments is that they support environmental conservation, amplified by the 2013 'greening' provisions. The Commission has accepted the weakness of the standard income support justification for the SFP, at least implicitly, by arguing that the payments are now to be justified as compensation for the provision of public goods - and, more particularly, environmental public goods. That said, the correlation between at least one indicator of environmental public goods (the proportion of utilized agricultural area designated as Natura 2000) ${ }^{69}$ and the 2013 level of direct payments is virtually non-existent at -0.075 (Figure 1.13). The correspondence between direct payments and the proportions of 'high nature value farmland' (Objective $18)^{70}$ is more strongly negative at -0.14 , which might perhaps suggest some modest level of encouragement to those receiving the higher payments per hectare to do more to

69 See Natura 2000 website (http://www.natura.org/about.html) for more details about this designation and associated network.

70 European Commission, Indicators for Rural Development Report (European Commission, 2010) Table 2.2.4.6. 
improve the nature value of their farmland, but otherwise is certainly no reward for those who already do so, either by accident or design.

No defensible justification is provided for the 30 per cent of direct payments to be conditional on compliance with agricultural practices beneficial for the climate and the environment. There is no suggestion in any of the environmental literature that common application throughout the EU of these measures can be especially effective in improving or even maintaining the environmental condition of the EU's cultivated land.$^{71}$ Likewise, there is no reason to suppose that these 'greening' measures can be efficient, even if they might prove remotely effective, with a key factor being the monitoring costs necessary for their uniform compliance. Accordingly, there appear to be only two rational reasons for their inclusion: first, as a transparent, and weak, public relations façade for the continuation of an otherwise obsolete and largely counter-productive direct payments system; and, second, as a deliberate attempt to make the receipt of direct payments sufficiently costly for larger scale commercial farmers that some will choose to opt out and farm without this support.

At the very least, environmental payments need to be targeted towards provision of specific public goods, which without doubt differ substantially across the EU. Matthews notes that annual average spending on CAP environmental payments will be increased fivefold through the 'greening' of Pillar I, yet at a time of severe public funding difficulties in Member States there is a serious question about what the environmental return is likely to be. ${ }^{72}$ Matthews' conclusion is the only logical and rational one, namely that the 30 per cent of Pillar I envelopes earmarked for 'greening' should be modulated to rural development measures under Pillar II, given their proven effectiveness as targeted measures.

\subsection{Majority Agreement on Redistribution?}

Despite the complete obsolescence and irrelevance of the income support and generalized environmental conservation arguments, the redistribution (or ultimate removal) of this support would necessarily damage current farm incomes and returns to factors of production, as Figure 1.10 above amply illustrates. Neither farmer organizations nor their political representatives can be expected to contemplate removal or reduction in these payments without some form of compensation, as with the removal of price support under the MacSharry reforms.

In 2010 the Commission advanced one possible policy option involving the progressive elimination of direct payments, ${ }^{73}$ which, perhaps not surprisingly, attracted no significant support in the reform negotiations and discussions. Without some explicit compensation,

71 See, e.g., Birdlife International, European Environmental Bureau, IFOAM EU Group and WWF, Common Briefing of BirdLife Europe, the European Environmental Bureau, the IFOAM EU Group and WWF Following Discussions in the Council on Greening of the CAP, June 2012 (available at http://www.eeb.org/?LinkServID=FC9DE42B-5056-B741-DB8F5A21DBFE76FA\&showMeta $=0 \& a a)$; and see generally A. Matthews, 'Greening agricultural payments in the EU's Common Agricultural Policy', (2013) 2(1) Bio-based and Applied Economics 1.

${ }_{72}$ A. Matthew, 'Greening the CAP: Which Way Forward?', Paper to the 126th EAAE Seminar: New Challenges for the EU Agricultural Sector and Rural Areas: Which Role for Public Policy?, Capri (27-29 June 2012).

73 European Commission, COM (2010) 672, The CAP towards 2020: meeting the food, natural resources and territorial challenges of the future, Annex, Option 3. 
the only alternative is a phased reduction, gradual elimination and atrophy towards more targeted, cross-compliant payments for environmental public goods, which logically and practically belong in Pillar II, not Pillar I, and should attract Member State co-funding.

There is, however, a compensation option - the 'CAP Bond' ${ }^{74}$ Rolling up an agreed and finite future stream of direct payments into a single lump sum (the bond) would clearly signal the end of the unsustainable direct payment system, compensate farmers for their loss of income and asset values, and provide secure and fungible compensation with which to adapt and adjust to life and markets without direct payments - entirely consistent with the adjustment assistance logic underpinning agricultural support.

\section{CONCLUSIONS}

The structure of European agriculture at the end of the first decade of the twenty-first century (Figure 1.14) echoes that of the founding states of the EU in the 1950s and 1960s, as noted in Figure 1.1 above.

As in Figure 1.1, agricultural structure is illustrated by the relative shares of agriculture in both GDP and employment. The closer these two shares are, the more competitive with the rest of the economy is the agricultural sector. Austria, Greece, Ireland, Portugal and Spain are examples among the ' 15 ' of Member States exhibiting poor agricultural structures, while the Baltic States, Poland, Slovenia, Croatia and Romania show particularly poor structures among the CEE states.

The agricultural sector 'gap' is illustrated by Figure 1.15. In this figure the Member States are reordered according to their net budgetary balance with the EU (the national contributions to the EU budget less the receipts from the budget). The approximate correspondence between national net budgetary contributions and the relative poverty of the agricultural sector is consistent with the broad economic characteristics of the stage of development. The richer Member States contribute more and receive less from the EU budget. In addition, they are characterized, broadly, with more balanced economies in the sense that their agricultural sectors have adjusted and adapted towards a more competitive balance with the rest of the economy.

The substantial redistribution of EU budget funds between Member States, which would follow the elimination (or even substantial reduction and possible renationalization) of direct payments, clearly raises problems for the Council and national (budgetary) interests in the CAP. However, Figure 1.15 suggests that there should be scope for renegotiation of the EU budget both to satisfy Member State requirements for agricultural adjustment and rural development assistance and to maintain current Member State interests in the distribution of the EU budget.

The state of and prospects for the CAP reflect what can be termed the 'Canute Problem 75 - the apparently eternal conundrum of the human condition that the intent

74 A. Jambor and D. Harvey, 'The CAP Bond revisited: a serious option for reform?', (2011) 10(1) Euro Choices 17; and see also A. Swinbank and R. Tranter (eds.), A Bond Scheme for Common Agricultural Policy Reform (CABI Publishing, 2004).

75 King Canute thought that he was sufficiently powerful to halt the incoming tide, so that he 'commanded that his chair should be set on the shore, when the tide began to rise. And then 


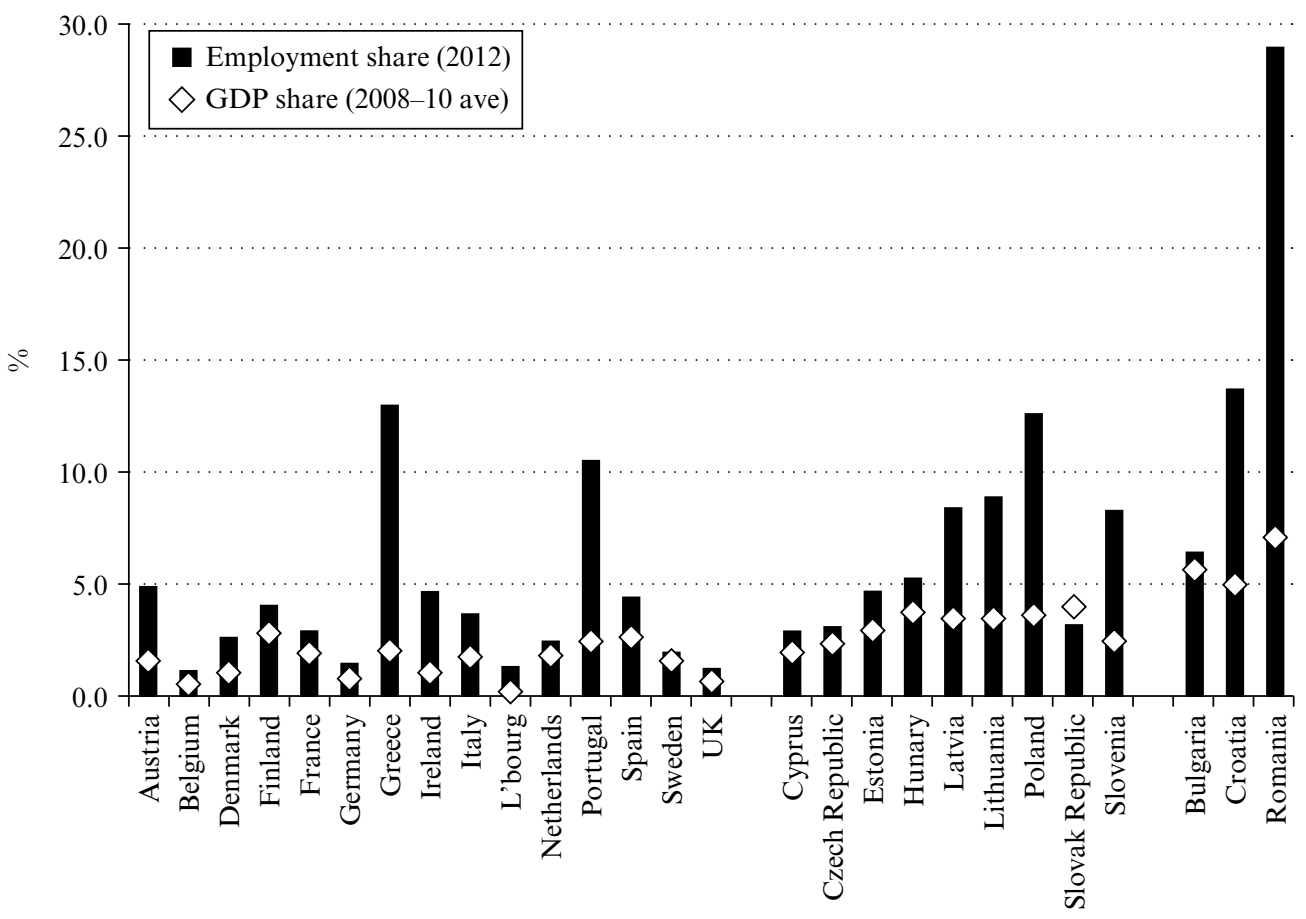

Source: Compiled from Eurostat Database at http://epp.eurostat.ec.europa.eu/portal/page/portal/statistics/ search_database (average 2008-10 for agriculture's share of GDP; and 2012 for agriculture's share of employment).

\section{Figure 1.14 European agriculture in 2010}

and purpose of human control and direction is continually frustrated by the inherent complexity and uncontrollability of both the natural and socio-economic systems we seek to control. From a conventional economic perspective, competitive economic systems are socially optimal unless there is a clear market failure. While agriculture is typically regarded as effectively competitive, the sector is characterized by (inter alia) differentiated products and transaction costs, concentrated suppliers and buyers, 'peasant' household firms, highly heterogeneous factors, imperfect knowledge and major environmental externalities, all of which can be economically argued to require public or government

he spoke to the rising sea saying "You are part of my dominion, and the ground that I am seated upon is mine, nor has anyone disobeyed my orders with impunity. Therefore, I order you not to rise onto my land, nor to wet the clothes or body of your Lord". But the sea carried on rising as usual without any reverence for his person, and soaked his feet and legs. Then he moving away said: "All the inhabitants of the world should know that the power of kings is vain and trivial, and that none is worthy the name of king but He whose command the heaven, earth and sea obey by eternal laws". Therefore King Cnut never afterwards placed the crown on his head, but above a picture of the Lord nailed to the cross, turning it forever into a means to praise God, the great king. By whose mercy may the soul of King Cnut enjoy peace' (Henry of Huntingdon, Chronicle). 


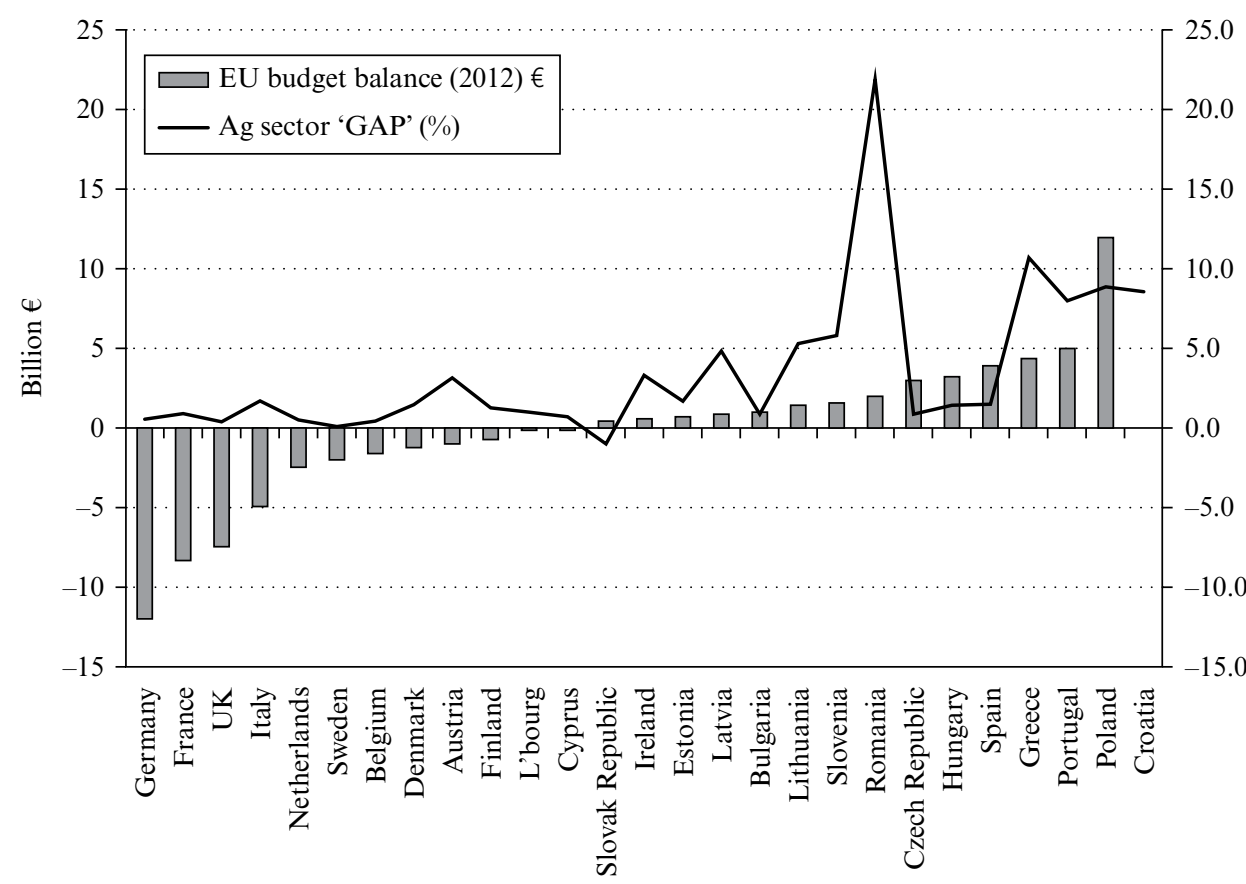

Sources: Compiled from Eurostat Database at http://epp.eurostat.ec.europa.eu/portal/page/portal/statistics/ search_database (average 2008-10 for agriculture's share of GDP; and 2012 for agriculture's share of employment); and EU Budget, Financial Report (2012).

\section{Figure 1.15 EU budgetary balances and agricultural structures}

intervention. However, the economically justified interventions are targeted and specific, not generalized direct payments. Furthermore, pure profits (in whatever ways generated) will tend to be eroded in this approximately competitive industry, so any support payments will be accumulated in factor rents (land) and in increased costs. In other words, attempts to improve the competitiveness of the sector will be self-defeating as the support increases the costs of the business. According to conventional economics, maintaining and improving competitiveness requires adjustment, adaptation and innovation to meet the 'tides' of (free) markets. The economic policy implications are: decouple, and then eliminate, generalized support; target assistance for public goods and market failures; support R\&D and extension; and enforce competition rules. Yet the CAP shows no prospects of moving fast in this direction.

The countervailing power over the evolution of the CAP is, of course, political, which is dominated by the status quo. Most political incentives, especially for individual elected politicians, are to resist or ameliorate change, protect vested interests, support the disadvantaged and respond to votes. The implications are that the CAP should be seen to help presently uncompetitive businesses and farms survive and persist - not least those which are small and disadvantaged - and to protect these numerous constituents against unjust markets, oligopolistic suppliers and buyers, and 'less favoured' environments. Besides, these political forces are more powerful the greater the number of small (uncompetitive) 
farms, the faster non-farm economic growth, the bigger the farm sector, and the greater the support dependencies (whether in supply chains and bureaucracies or among farms). The political policy imperatives are therefore to retain and justify historic support, limited to those most 'deserving' (in other words, those currently most uncompetitive) and further justified by 'public/merit' goods and services arguments. This, evidently, is the current driving force for CAP 'reform'. Nonetheless, there will surely come a time when the political forces currently driving both the CAP and the EU budget will realize that the tides of economic development and market forces cannot be commanded to reverse at the political will. 